\title{
Ecology of Gymnodinium aureolum. II. Predation by common heterotrophic dinoflagellates and a ciliate
}

\author{
Yeong Du Yoo', Hae Jin Jeong ${ }^{1, *}$, Nam Seon Kang ${ }^{1}$, Jae Seong Kim², \\ Tae Hoon $\mathrm{Kim}^{3}$, Eun Young Yoon ${ }^{1}$ \\ ${ }^{1}$ School of Earth and Environmental Sciences, College of Natural Sciences, Seoul National University, \\ Seoul 151-747, Republic of Korea \\ ${ }^{2}$ Red Tide Research Center, Kunsan National University, Kunsan 573-701, Republic of Korea \\ ${ }^{3}$ Department of Oceanography, Kunsan National University, Kunsan 573-701, Republic of Korea
}

\begin{abstract}
We investigated whether the common heterotrophic dinoflagellates Gyrodinium dominans, Oxyrrhis marina, Pfiesteria piscicida, Polykrikos kofoidii, Protoperidinium bipes and Stoeckeria algicida, and the naked ciliate Strombidinopsis sp., were able to feed on the mixotrophic red-tide dinoflagellate Gymnodinium aureolum (GenBank accession no. FN392226). We also measured the growth and ingestion rates of G. dominans, O. marina, P. kofoidii, and Strombidinopsis sp. on G. aureolum as a function of prey concentration. We calculated grazing coefficients by combining field data on abundance of small Gyrodinium spp. (25 to $35 \mu \mathrm{m}$ in cell length) and Strombidinopsis spp. $(>70 \mu \mathrm{m})$ and co-occurring $G$. aureolum with laboratory data on ingestion rates obtained in this study. G. dominans, O. marina, P. kofoidii, and Strombidinopsis sp. were able to feed on G. aureolum, whereas $P$. piscicida, $P$. bipes, and $S$. algicida were not. The maximum growth rates of G. dominans, O. marina, Strombidinopsis sp. and P. kofoidii on G. aureolum were 0.92, 0.71, 0.44 and $0.11 \mathrm{~d}^{-1}$, respectively. However, the maximum ingestion rates of $G$. dominans on $G$. aureolum (2.0 ng C predator $^{-1} \mathrm{~d}^{-1}$ ) were comparable with that of $P$. kofoidii (2.3 ng C predator ${ }^{-1} \mathrm{~d}^{-1}$ ), but much lower than that of Strombidinopsis sp. (69.7 ng C predator ${ }^{-1} \mathrm{~d}^{-1}$ ). Calculated grazing coefficients for small heterotrophic Gyrodinium spp. and large Strombidinopsis spp. on G. aureolum were up to $0.40 \mathrm{~d}^{-1}$ and $0.25 \mathrm{~d}^{-1}$, respectively (i.e. up to 33 and $22 \%$ of $G$. aureolum populations were removed by small Gyrodinium and Strombidinopsis populations in $1 \mathrm{~d}$, respectively). The results of the present study suggest that small Gyrodinium spp. and Strombidinopsis sp. sometimes have considerable grazing effect on populations of G. aureolum.
\end{abstract}

KEY WORDS: Graze $\cdot$ Growth $\cdot$ Harmful algal bloom $\cdot$ Ingestion $\cdot$ Protist $\cdot$ Red tide

\section{INTRODUCTION}

The dinoflagellate Gyrodinium aureolum was first described by Hulburt (1957) and had been considered a common bloom-forming species in temperate waters (Tangen 1977, Potts \& Edwards 1987, Nielsen \& Tønseth 1991, Blasco et al. 1996). However, considerable confusion arose regarding identity of this species. An isolate from the Pettaquamscutt River, USA, which was similar to the original description of Gyrodinium aure- olum by Hulburt (1957), was designated as Gymnodinium aureolum, while the European isolates that were formerly identified as Gyrodinium aureolum, Gymnodinium nagasakiense and Gymnodinium mikimotoi were finally designated as Karenia mikimotoi (Daugbjerg et al. 2000, Hansen et al. 2000). Gymnodinium aureolum has a horseshoe-shaped apical groove, nuclear chambers and a nuclear fibrous connective (NFC), while $K$. mikimotoi has a linear apical groove and does not have a nuclear chamber or a NFC. 
At present, it is difficult to determine whether Gyrodinium aureolum isolates reported by researchers before Daugbjerg et al. (2000) and Hansen et al. (2000) were Gymnodinium aureolum or K. mikimotoi. Thus, there have been only a few studies on the ecophysiology of the actual Gymnodinium aureolum species since settlement of the confusion over taxonomy (Tang et al. 2008, Jeong et al. 2010, this issue).

Jeong et al. (2010) revealed that Gymnodinium aureolum, originally thought to be an exclusively autotrophic dinoflagellate, is a mixotrophic dinoflagellate. The population dynamics of a mixotrophic dinoflagellate are affected mainly by growth and mortality. However, to date, no studies exist on mortality of G. aureolum caused by predation. Even for Karenia mikimotoi, only a few studies have been done to determine its mortality resulting from predation (Lee \& Hirayama 1992, Nakamura et al. 1995, Kamiyama \& Arima 2001); Nakamura et al. (1995) reported that the heterotrophic dinoflagellate Gyrodinium dominans had a growth rate of 0.4 to $0.7 \mathrm{~d}^{-1}$ when they fed on K. mikimotoi (previously Gymnodinium mikimotoi). Another heterotrophic dinoflagellate Noctiluca scintillans was able to feed on K. mikimotoi (previously G. nagasakiense) (Lee \& Hirayama 1992). Also, a Japanese strain of Favella ehrenbergii was able to feed on a strain of $K$. mikimotoi although its ingestion rate (based on carbon biomass) was lower than that when it fed on other mixotrophic dinoflagellate prey, with the exception of Prorocentrum triestinum (Kamiyama \& Arima 2001). The heterotrophic dinoflagellate Diplopsalis lenticula was shown to feed on Gyrodinium aureolum, although it remains unclear whether this prey was Gymnodinium aureolum or K. mikimotoi (Naustvoll 1998). To understand the ecology of Gymnodinium aureolum in natural environments, it is necessary to explore mortality of $G$. aureolum due to predation by using a clearly identified culture of $G$. aureolum.

Karenia mikimotoi is known to produce undefined toxic compounds and is harmful to the ciliate Favella ehrenbergii, copepods, larvae of benthos and fish (Gill \& Harris 1987, Uye \& Takamatsu 1990, Hansen 1995, Smolowitz \& Shumway 1997, Yamasaki et al. 2004). However, the toxins or toxic compounds of Gymnodinium aureolum have not been detected. Tang et al. (2008) reported that the juvenile fish Cyprinodon variegate was not killed when exposed to 3 strains of $G$. aureolum at concentrations of 10900 to 14500 cells $\mathrm{ml}^{-1}$. Jeong et al. (2010) also reported that the Korean strain of $G$. aureolum used in the present study did not kill the brine shrimp Artemia salina at the concentrations of 4940 to 15180 cells ml ${ }^{-1}$. Therefore, unlike $K$. mikimotoi, G. aureolum is likely to be a non-toxic dinoflagellate, and the interactions between $G$. aureolum and predators may be quite different from those between $K$. mikimotoi and predators. To understand the population dynamics of $G$. aureolum and its potential predators in natural environments, it is necessary to explore the interactions between $G$. aureolum and potential predators.

In general, the grazing effects of heterotrophic dinoflagellates or ciliates on red tide dinoflagellates are much higher than that of copepods, as the abundances of heterotrophic dinoflagellates or ciliates are much greater than that of copepods (i.e. usually 100 to 10000 times greater) even though the ingestion rates of heterotrophic dinoflagellates or ciliates are considerably lower (i.e. usually 10 to 100 times lower) (Calbet et al. 2003, Calbet \& Landry 2004, Kim \& Jeong 2004, Turner \& Borkman 2005). Therefore, to investigate grazing pressure by potential predators on Gymnodinium aureolum, growth, ingestion and mortality of G. aureolum due to predation by heterotrophic dinoflagellates and ciliates need to be measured.

Recently Gymnodinium aureolum has formed red tides off the western coasts of Korea. We isolated and established a clonal culture of the dinoflagellate during a red tide event dominated by G. aureolum in 2008. During this red tide, we found several ciliates and heterotrophic dinoflagellates; therefore, it is highly possibile that some of these ciliates and heterotrophic dinoflagellates feed on $G$. aureolum. By using this culture, we observed feeding behavior, examined the kind of prey consumed and measured growth and grazing rates of this species (Jeong et al. 2010). The present study also investigated feeding by 6 common heterotrophic dinoflagellates and one ciliate on this dinoflagellate. We (1) tested whether the heterotrophic dinoflagellates Gyrodinium dominans, Oxyrrhis marina, Pfiesteria piscicida, Polykrikos kofoidii, Protoperidinium bipes and Stoeckeria algicida and the ciliate Strombidinopsis sp. were able to feed on G. aureolum; (2) measured the growth and/or ingestion rates of $G$. dominans, O. marina, P. kofoidii and Strombidinopsis sp. on $G$. aureolum as a function of prey concentration; and (3) calculated grazing coefficients by combining field data on abundance of G. dominans (or Strombidinopsis sp.) and co-occurring G. aureolum with laboratory data on ingestion rates obtained in this study.

The results of the present study provide a basis for understanding the interactions between Gymnodinium aureolum and heterotrophic protists and their population dynamics in marine planktonic food webs.

\section{MATERIALS AND METHODS}

Preparation of experimental organisms. For isolation and culture of Gymnodinium aureolum (GenBank accession no. FN392226), plankton samples were col- 
lected with water samplers from the waters off Saemankeum, Korea, during March 2008 when the water temperature and salinity were $10.0^{\circ} \mathrm{C}$ and 30.5 , respectively (Table 1). These samples were gently passed through a $154 \mu \mathrm{m}$ Nitex mesh screen and placed in 6well tissue culture plates. A clonal culture of G. aureolum was established by 2 serial single cell isolations. As the concentration of $G$. aureolum increased, $G$. aureolum was subsequently transferred to $32,120,270$ and $500 \mathrm{ml}$ polycarbonate (PC) bottles (Nalge Nunc International) containing fresh $\mathrm{f} / 2$ seawater media. The bottles were filled to capacity with freshly filtered seawater, capped and placed on a shelf at $20^{\circ} \mathrm{C}$ under an illumination of $20 \mu \mathrm{E} \mathrm{m} \mathrm{m}^{-2} \mathrm{~s}^{-1}$ of cool white fluorescent light on a $14 \mathrm{~h}$ light: $10 \mathrm{~h}$ dark cycle.

For the isolation and culture of the heterotrophic dinoflagellate predators Gyrodinium dominans, Oxyrrhis marina, Polykrikos kofoidii, Pfiesteria piscicida, Steockeria algicida and Protoperidinium bipes, plankton samples were collected with water samplers from the coastal waters off Masan, Incheon or Shiwha, Korea, from 2001 to 2008, and a clonal culture of each species was established by 2 serial single-cell isolations (Table 1).

For the isolation and culture of Strombidinopsis sp., plankton samples were collected with water samplers from a pier in Masan Bay, Korea, during May 2009 when the water temperature and salinity were $20.2^{\circ} \mathrm{C}$ and 30.1, respectively (Table 1). A clonal culture of Strombidinopsis sp. (70 to $160 \mu \mathrm{m}$ in cell length) was established by 2 serial single cell isolations as described by Jeong et al. (2008a).

The carbon contents for Gymnodinium aureolum (0.44 ng C per cell, $\mathrm{n}=50$ ), the heterotrophic dinoflagellates and the ciliate were estimated from cell volume according to Menden-Deuer \& Lessard (2000). The cell volume of the predators was estimated by means of the following methods: Kim \& Jeong (2004) for Gyrodinium dominans; Jeong et al. (2008b) for Oxyrrhis marina; Jeong et al. (2003a) for Polykrikos kofoidii; Jeong et al. (2007) for Pfiesteria piscicida and
Steockeria algicida; Jeong et al. (2004) for Protoperidinium bipes; and Jeong et al. (2008a) for Strombodinopsis sp.

Feeding occurrence. Expt 1 was designed to test whether each of Gyrodinium dominans, Oxyrrhis marina, Pfiesteria piscicida, Polykrikos kofoidii, Protoperidinium bipes, Stoeckeria algicida and Strombidinopsis sp. was able to feed on Gymnodinium aureolum (Table 2).

Approximately $8 \times 10^{5}$ Gymnodinium aureolum cells were added to each of two $80 \mathrm{ml}$ PC bottles containing Polykrikos kofoidii (100 cells $\mathrm{ml}^{-1}$ ), each of the other heterotrophic dinoflagellates (1000 to 5000 cells ml $^{-1}$ ), or the ciliate ( 20 cells $\mathrm{ml}^{-1}$ ) (final prey concentration ca. 10000 cells $\mathrm{ml}^{-1}$ ). One control bottle (without prey) was set up for each experiment. The bottles were placed on a plankton wheel rotating at $0.9 \mathrm{rpm}$ and incubated at $20^{\circ} \mathrm{C}$ under an illumination of $20 \mu \mathrm{E} \mathrm{m} \mathrm{m}^{-2}$ $\mathrm{s}^{-1}$ on a $14 \mathrm{~h}$ light:10 h dark cycle.

Aliquots of $5 \mathrm{ml}$ were removed from each bottle after $1,2,6$ and $24 \mathrm{~h}$ incubation and then transferred into 6 well plate chambers (or glass microscope slides). Approximately 200 cells of each predator in the plate chamber (or glass microscope slide) were observed under a dissecting microscope (or inverted microscope) at a magnifications ranging from 20 to $90 \times$ (or 100 to $630 \times$ ) to determine whether the predator was able to feed on the Gymnodinium aureolum. Cells of the predator containing ingested G. aureolum cells were photographed at a magnification of 400 to $630 \times$ with a digital camera (Zeiss AxioCam HRc5, Carl Zeiss) mounted on the microscope.

Growth and ingestion rates. Expts 2 to 5 were designed to measure the growth and ingestion rates of Gyrodinium dominans, Oxyrrhis marina, Polykrikos kofoidii and Strombidinopsis sp. as a function of the prey concentration when they fed on Gymnodinium aureolum (Table 2). Only these 3 heterotrophic dinoflagellates and the ciliate were shown to feed on G. aureolum among the heterotrophic protists tested.

Table 1. Isolation and maintenance conditions of the experimental organisms. Sampling location and time, water temperature ( $T$, ${ }^{\circ} \mathrm{C}$ ) and salinity for isolation, and prey species and concentrations (cells $\mathrm{ml}^{-1}$ ) for maintenance. MTD: mixotrophic dinoflagellate; HTD: heterotrophic dinoflagellate; CIL: ciliate

\begin{tabular}{|lcccccc|}
\hline Organism & Location & Date & $T$ & Salinity & Prey species & Concentration \\
\hline Gyrodinium dominans (HTD) & Masan Bay & Apr 2007 & 15.1 & 33.4 & Amphidinium carterea & $30000-40000$ \\
Oxyrrhis marina (HTD) & Keum Estuary & May 2001 & 16.0 & 27.7 & Amphidinium carterea & 8000 \\
Polykrikos kofoidii (HTD) & Masan Bay & Jun 2007 & 20.2 & 32.2 & Lingulodinium polyedrum & 4000 \\
Strombidinopsis sp. (CIL) & Masan Bay & May 2009 & 20.2 & 30.1 & Prorocentrum minimum & $20000-30000$ \\
Pfiesteria piscicida (HTD) & Off Incheon & Jul 2005 & 24.0 & 25.4 & Amphidinium carterea & $20000-30000$ \\
Stoeckeria algicida (HTD) & Masan Bay & May 2007 & 20.9 & 30.1 & Heterosigma akashiwo & 30000 \\
Protoperidinium bipes (HTD) & Shiwha Bay & Nov 2008 & 13.0 & 28.5 & Skeletonema costatum & 50000 \\
Gymnodinium aureolum (MTD) & Off Saemankeum & Mar 2008 & 10.0 & 30.5 & & \\
& & & & & & \\
\hline
\end{tabular}


Table 2. Experimental design to assess predation on Gymnodinium aureolum by various planktonic predator species. The numbers in prey and predator columns are the actual initial concentrations (cells $\mathrm{ml}^{-1}$ ) of prey and predator. In each experiment, the lowest G. aureolum concentration was tested against the lowest predator concentration, the next lowest against the next lowest, etc. Values within parentheses in the prey and predator columns are the corresponding prey and predator concentrations in the predator-only control bottles. Feeding occurrence of each predator fed Gymnodinium aureolum in Expt 1 is represented by $\mathrm{Y}$ (feeding observed) or N (no feeding observed)

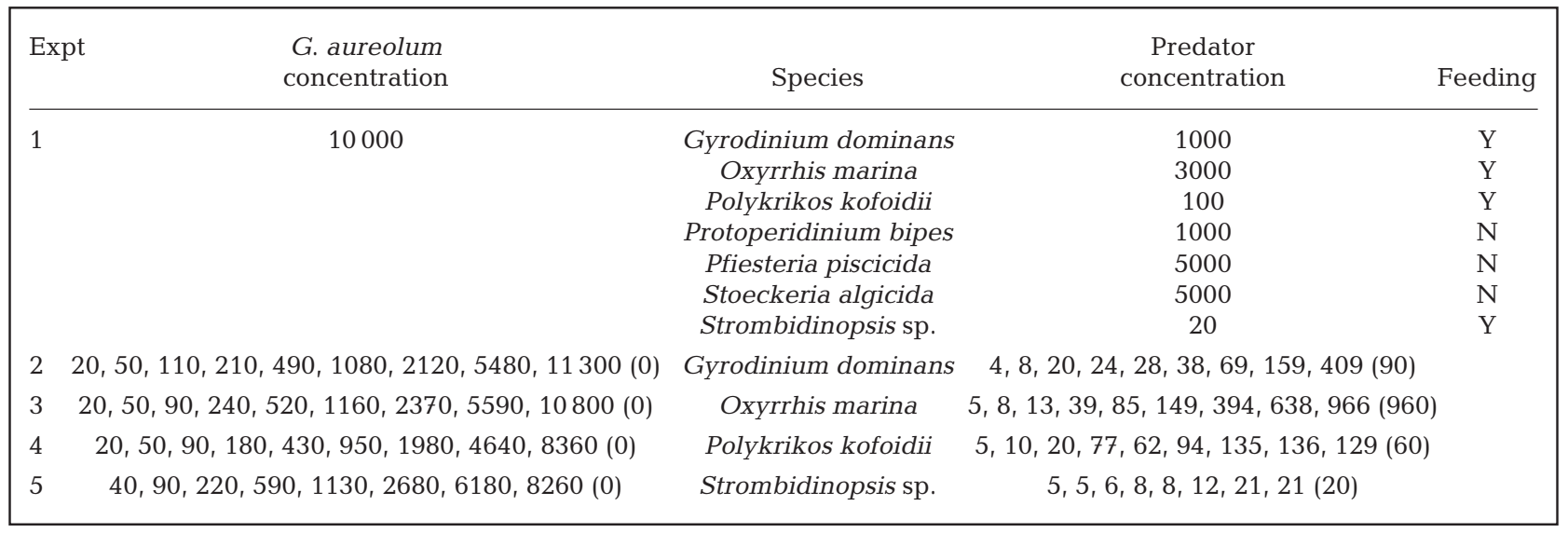

The day before these experiments were conducted, dense cultures of predator species growing on algal prey were transferred into $500 \mathrm{ml}$ PC bottles containing 2 different concentrations of the target prey as follows: (1) ca. 100 Gymnodinium aureolum cells $\mathrm{ml}^{-1}$ for 5 lower prey concentrations and ca. 500 G. aureolum cells $\mathrm{ml}^{-1}$ for 4 upper prey concentrations for G. dominans; (2) ca. 200 G. aureolum cells $\mathrm{ml}^{-1}$ for 4 lower prey concentrations and ca. 1000 G. aureolum cells $\mathrm{ml}^{-1}$ for 5 upper prey concentrations for Oxyrrhis marina; (3) ca. $100 \mathrm{G}$. aureolum cells $\mathrm{ml}^{-1}$ for 5 lower prey concentrations and ca. 500 G. aureolum cells ml $\mathrm{m}^{-1}$ for 4 upper prey concentrations for Polykrikos kofoidii; (4) ca. 300 G. aureolum cells $\mathrm{ml}^{-1}$ for 4 lower prey concentrations and ca. 1500 G. aureolum cells $\mathrm{ml}^{-1}$ for 4 upper prey concentrations for Strombidinopsis sp. The use of two different concentrations was meant to minimize possible residual growth resulting from the ingestion of prey during batch culture. The bottles were filled to capacity with freshly filtered seawater, capped and placed on plankton wheels rotating at $0.9 \mathrm{rpm}$ and incubated at $20^{\circ} \mathrm{C}$ under the illumination of $20 \mu \mathrm{E} \mathrm{m} \mathrm{m}^{-2}$ $\mathrm{s}^{-1}$ on a $14 \mathrm{~h}$ light: $10 \mathrm{~h}$ dark cycle. To monitor the conditions and interaction between predator and prey species, the cultures were periodically removed from the rotating wheels, examined by observation through the surface of the capped bottles by means of a dissecting microscope (Olympus SZX12, Olympus) and returned to the rotating wheels. Once the target prey cells were no longer detectable, three $1 \mathrm{ml}$ aliquots from each bottle were viewed under a light microscope (Olympus BX51, Olympus) and counted to determine cell concentrations of predator species, and the cultures were then used to conduct these experiments.
For each experiment, the initial concentrations of predator species and Gymnodinium aureolum were established by means of an autopipette that delivered predetermined volumes of known cell concentrations to the bottles. In preliminary tests, ingestion rates, and in turn growth rates, of a predator on prey at low prey concentrations were lower than those at higher prey concentrations. After incubation, ratios of predator relative to prey at low prey concentrations usually decreased (i.e. predator concentration slowly increased, remained unchanged or decreased, whereas prey concentration slowly decreased or remained unchanged), while those at high prey concentrations increased (i.e. predator concentration rapidly increased, whereas prey concentration rapidly decreased). Thus, we established higher initial ratios of predator relative to prey at low prey concentrations than for those at high prey concentrations. Triplicate $42 \mathrm{ml}$ PC experiment bottles $(80 \mathrm{ml}$ bottles for the ciliate) containing mixtures of predator and prey and triplicate control bottles (prey only) were set up at each predator-prey combination. Triplicate control bottles containing only predator species were also established at one predator concentration. To obtain similar water conditions, the water of a predator culture was filtered through a $0.7 \mu \mathrm{m}$ GF/F filter and then added to the prey control bottles in the same volume that was added to the experiment bottles for each predator-prey combination. All bottles were then filled to capacity with freshly filtered seawater and capped. To determine the actual predator and prey concentrations at the beginning of the experiment, a $5 \mathrm{ml}$ aliquot was removed from each bottle, fixed with $5 \%$ Lugol's solution and examined with a 
light microscope to determine predator and prey abundance by enumerating the cells in three $1 \mathrm{ml}$ Sedgwick-Rafter chambers (SRCs). The bottles were refilled to capacity with freshly filtered seawater, capped and placed on rotating wheels under the conditions described above. Dilution of the cultures associated with refilling the bottles was considered when calculating growth and ingestion rates. A $10 \mathrm{ml}$ aliquot was taken from each bottle after $48 \mathrm{~h}$ incubation ( $24 \mathrm{~h}$ incubation for the ciliate) and fixed with $5 \%$ Lugol's solution. The abundance of predator species and the prey were determined by counting all or $>300$ cells in three $1 \mathrm{ml}$ SRCs. Before taking the subsamples, the condition of predator species and the prey was assessed by means of a dissecting microscope as described above.

The specific growth rate of predator species, $\mu\left(\mathrm{d}^{-1}\right)$, was calculated as:

$$
\mu=\ln \left(P_{t} / P_{0}\right) / t
$$

where $P_{0}$ and $P_{t}$ are the concentrations of predator species at 0 and $48 \mathrm{~h}$ (or $24 \mathrm{~h}$ for the ciliate), respectively.

We tested $>100$ curve fittings for the data on the growth rate of each predator on Gymnodinium aureolum using TableCurve ${ }^{\circledR} 2 \mathrm{D}$ v.5.01 (SYSTAT Software) and found best curve fits for each predator. Best curve fits for the data on growth and ingestion rates of Gyrodinium dominans, Oxyrrhis marina and Strombidinopsis sp. on G. aureolum were a MichaelisMenten equation or Ivlev equation. The coefficients of determination $\left(\mathrm{r}^{2}\right)$ of the Michaelis-Menten equation and Ivlev equation for growth and ingestion rates of each predator were very similar, and thus, we provided both curve fits. The Michaelis-Menten equation for growth rate data was:

$$
\mu=\mu_{\max }\left(X-X^{\prime}\right) /\left[K_{\mathrm{GR}}+\left(X-X^{\prime}\right)\right]
$$

where $\mu_{\max }=$ maximum growth rate $\left(\mathrm{d}^{-1}\right), X=$ prey concentration (cells ml ${ }^{-1}$ or ng $\mathrm{C} \mathrm{ml}^{-1}$ ), $X^{\prime}=$ threshold prey concentration (the prey concentration where $\mu=0$ ) and $K_{\mathrm{GR}}=$ prey concentration sustaining $1 / 2 \mu_{\max }$. Data were iteratively fitted to the model using DeltaGraph ${ }^{\circledR}$ (Delta Point). The Ivlev equation for growth rate $\left(\mu, \mathrm{d}^{-1}\right)$ data was:

$$
\mu=\mu_{\max }\left[1-\mathrm{e}^{-k\left(X-X^{\prime}\right)}\right]
$$

where $\mu_{\max }=$ the maximum growth rate $\left(\mathrm{d}^{-1}\right), X=$ prey concentration (cells ml-1 or ng $\mathrm{C} \mathrm{ml}^{-1}$ ), $X^{\prime}=$ threshold prey concentration (the prey concentration where $\mu=$ 0 ) and $k=$ constant. Data were iteratively fitted to the model using DeltaGraph.

Ingestion and clearance rates were calculated using the equations of Frost (1972) and Heinbokel (1978). The incubation times for calculating ingestion and clearance rates were the same as those for estimating growth rate. The Michaelis-Menten equation for ingestion rate (IR, cells predator ${ }^{-1} \mathrm{~d}^{-1}$ or ng $\mathrm{C}$ predator $^{-1} \mathrm{~d}^{-1}$ ) data was:

$$
\mathrm{IR}=I_{\max } X /\left(K_{\mathrm{IR}}+X\right)
$$

where $I_{\max }=$ maximum ingestion rate (cells predator ${ }^{-1}$ $\mathrm{d}^{-1}$ or ng $\mathrm{C}$ predator $\left.{ }^{-1} \mathrm{~d}^{-1}\right), X=$ prey concentration (cells $\mathrm{ml}^{-1}$ or $\mathrm{ng} \mathrm{C} \mathrm{ml}^{-1}$ ) and $K_{\mathrm{IR}}=$ prey concentration sustaining $1 / 2 I_{\max }$. The Ivlev equation for ingestion rate data was:

$$
\mathrm{IR}=I_{\max }\left(1-\mathrm{e}^{-k X}\right)
$$

where $I_{\max }=$ maximum ingestion rate (cells predator $^{-1}$ $\mathrm{d}^{-1}$ or ng $\mathrm{C}$ predator $\left.{ }^{-1} \mathrm{~d}^{-1}\right), X=$ prey concentration (cells $\mathrm{ml}^{-1}$ or ng $\mathrm{C} \mathrm{ml}^{-1}$ ) and $k=$ constant. Data were iteratively fitted to the model using DeltaGraph ${ }^{\circledR}$.

Growth rate data of Polykrikos kofoidii were not well fitted to any equation. The best curve fit for ingestion rate data of $P$. kofoidii was a logistic curve fit as follows:

$$
\mathrm{IR}=I_{\max } \ln (X+A)+B
$$

where $I_{\max }=$ maximum ingestion rate (cells predator $^{-1} \mathrm{~d}^{-1}$ or ng $\mathrm{C}$ predator $\left.{ }^{-1} \mathrm{~d}^{-1}\right), X=$ prey concentration (cells $\mathrm{ml}^{-1}$ or $\mathrm{ng} \mathrm{C} \mathrm{ml}^{-1}$ ) and $A$ and $B$ are constants. Data were iteratively fitted to the model using DeltaGraph. However, the value extrapolated using this curve when prey concentration was zero (i.e. no prey) was positive (i.e. feeding occurred). Therefore, this curve is valid only when the prey concentration is larger than a certain prey concentration.

Gross growth efficiency. Gross growth efficiency (GGE), defined as predator biomass produced $(+)$ or lost (-) per prey biomass ingested, was calculated from estimates of carbon content per cell based on cell volume for each mean prey concentration.

Grazing impact. We estimated grazing coefficients attributable to small heterotrophic Gyrodinium spp. (25 to $35 \mu \mathrm{m}$ in cell length) or large Strombidinopsis spp., (>70 $\mathrm{mm}$ in cell length) on Gymnodinium aureolum by combining field data on abundances of small Gyrodinium spp. (or Strombidinopsis sp.) and prey with ingestion rates of the predators on the prey obtained in the present study. We assumed that the ingestion rates of the other small heterotrophic Gyrodinium spp. (or Strombidinopsis spp.) on G. aureolum are the same as that of Gyrodinum dominans (or Strombidinopsis sp.). The data on the abundances of G. aureolum and co-occurring small heterotrophic Gyrodinium spp. (or Strombidinopsis spp.) used in this estimation were obtained from water samples collected from 2006 to 2008 from the coastal waters off Saemankeum, at fixed stations. The grazing coefficients $\left(g, \mathrm{~d}^{-1}\right)$ were calculated as: 


$$
g=\mathrm{CR} \times P \times 24
$$

where CR is the clearance rate $\left(\mathrm{ml}\right.$ predator $\left.^{-1} \mathrm{~h}^{-1}\right)$ of a predator on Gymnodinium aureolum at a given prey concentration and $P$ is the predator concentration (cells $\mathrm{ml}^{-1}$ ). CRs were calculated as:

$$
\mathrm{CR}=\operatorname{IR}(\mathrm{h}) / X
$$

where IR(h) is the ingestion rate (cells eaten predator $^{-1}$ $\mathrm{h}^{-1}$ ) of the predator on the prey and $X$ is the prey concentration (cells ml ${ }^{-1}$ ). CRs were corrected using $Q_{10}=$ 2.8 (Hansen et al. 1997) because in situ water temperatures and the temperature used in the laboratory for this experiment $\left(20^{\circ} \mathrm{C}\right)$ were sometimes different. ted to Eq. (2), the $\mu_{\max }$ of $O$. marina feeding on G. aureolum was $0.71 \mathrm{~d}^{-1}$. The feeding threshold prey concentration for the growth of the predator (no growth) in Eq. (2) was $8 \mathrm{ng} \mathrm{C} \mathrm{ml}^{-1}$ (18 cells ml $\mathrm{m}^{-1}$ ). However, when the data were fitted to Eq. (3), the $\mu_{\max }$ of $O$. marina feeding on $G$. aureolum was $0.65 \mathrm{~d}^{-1}$. The feeding threshold prey concentration in Eq. (3) was $9 \mathrm{ng} \mathrm{C} \mathrm{ml}^{-1}$ (20 cells ml $\mathrm{m}^{-1}$ ).

The specific growth rates of Polykrikos kofoidii feeding on Gymnodinium aureolum increased with increasing mean prey concentration (Fig. 2C). The growth rates were negative at mean prey concentrations <830 ng C ml-1 $\left(<1900\right.$ cells $\left.\mathrm{ml}^{-1}\right)$, but positive at mean prey concentrations $>2090 \mathrm{ng} \mathrm{C} \mathrm{ml}^{-1}$ $\left(>4750\right.$ cells $\left.\mathrm{ml}^{-1}\right)$. At the given prey concentrations,

\section{RESULTS}

\section{Feeding occurrence and growth rate}

Gyrodinium dominans, Oxyrrhis marina, Polykrikos kofoidii and Strombidinopsis sp. were able to feed on Gymnodinium aureolum, while Pfiesteria piscicida, Protoperidinium bipes and Stoeckeria algicida were not (Fig. 1). P. piscicida, P. bipes and S. algicida were observed not to deploy a tow filament to capture $G$. aureolum cells.

The specific growth rates of Gyrodinium dominans feeding on Gymnodinium aureolum increased rapidly with increasing mean prey concentration up to ca. $445 \mathrm{ng} \mathrm{C} \mathrm{ml}^{-1}$ (1010 cells $\mathrm{ml}^{-1}$ ), but became saturated at higher concentrations (Fig. 2A). When the data were fitted to Eq. (2), the maximum specific growth rate $\left(\mu_{\max }\right)$ of $G$. dominans feeding on $G$. aureolum was $0.92 \mathrm{~d}^{-1}$. The feeding threshold prey concentration for the growth of the predator (no growth) in Eq. (2) was $76 \mathrm{ng} \mathrm{C} \mathrm{ml}^{-1}$ (173 cells ml ${ }^{-1}$ ). However, when the data were fitted to Eq. (3), the $\mu_{\max }$ of $G$. dominans feeding on $G$. aureolum was $0.79 \mathrm{~d}^{-1}$. The feeding threshold prey concentration in Eq. (3) was $86 \mathrm{ng} \mathrm{C} \mathrm{ml}^{-1}$ (195 cells $\mathrm{ml}^{-1}$ ).

The specific growth rates of Oxyrrhis marina feeding on Gymnodinium aureolum increased rapidly with increasing mean prey concentration up to ca. 80 ng $\mathrm{C} \mathrm{ml}$ (180 cells $\left.\mathrm{ml}^{-1}\right)$, but became saturated at higher concentrations (Fig. 2B). When the data were fit-
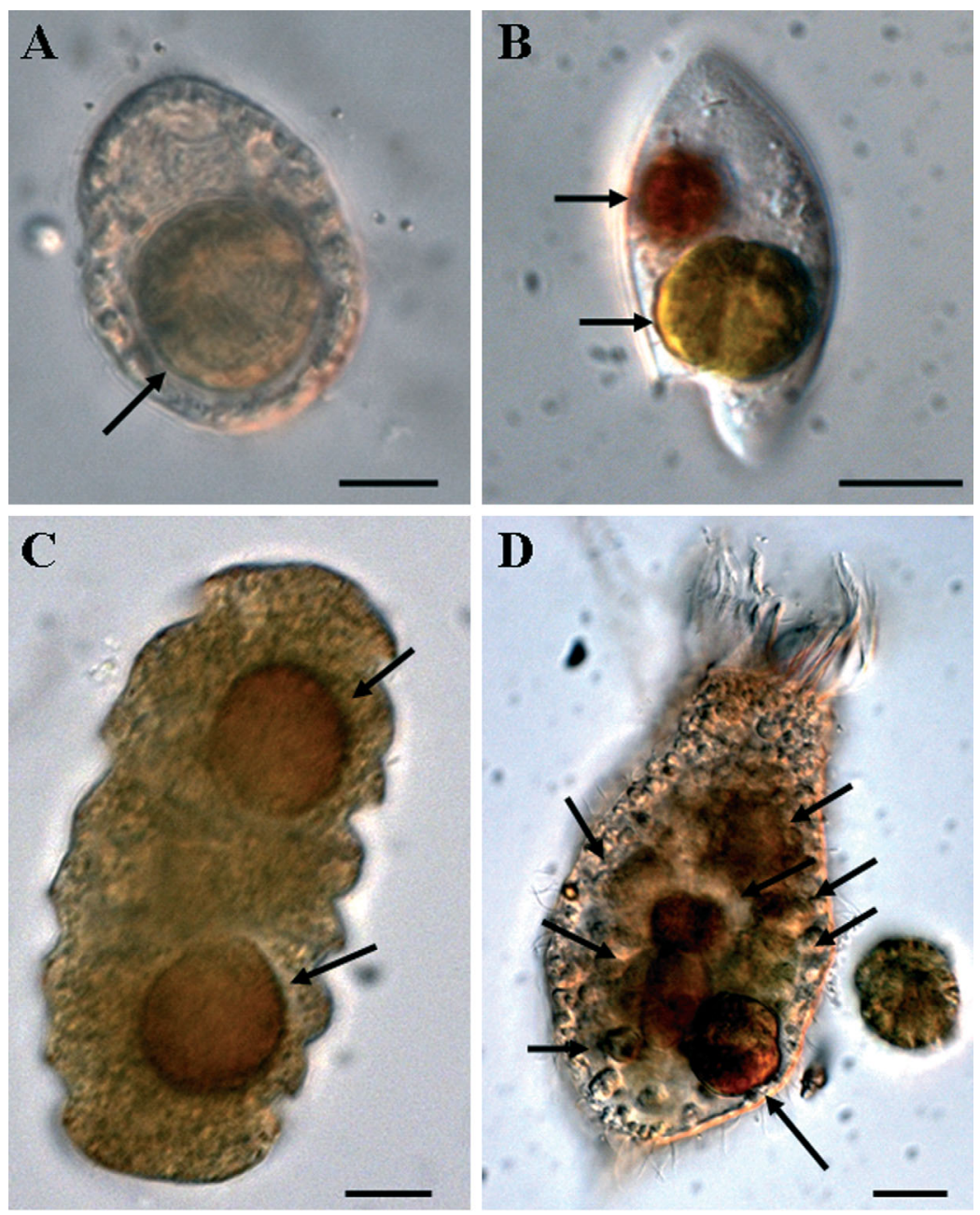

Fig. 1. Feeding by (A-C) heterotrophic dinoflagellates and (D) a ciliate on the mixotrophic dinoflagellate Gymnodinium aureolum. (A) Gyrodinium dominans with an ingested G. aureolum cell, (B) Oxyrrhis marina with 2 ingested G. aureolum cells, (C) Polykrikos kofoidii with 2 ingested G. aureolum cells, (D) Strombidinopsis sp. with several ingested $G$. aureolum cells. Arrows indicate ingested prey cells. All photographs were taken by means of an inverted microscope. Scale bars $=10 \mu \mathrm{m}$ 

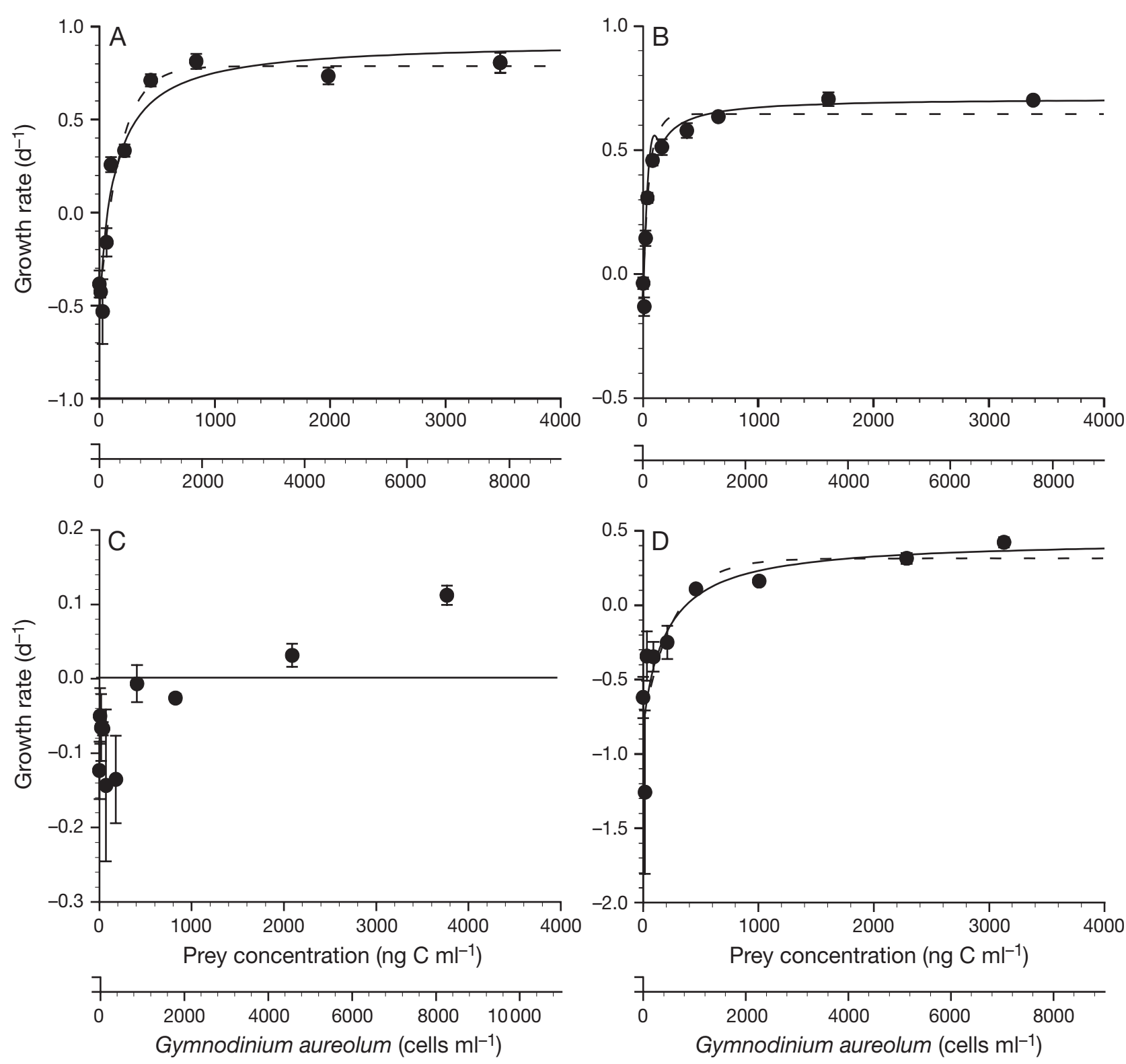

Fig. 2. Specific growth rates $\left(\mu, \mathrm{d}^{-1}\right)$ of the heterotrophic dinoflagellates and a ciliate feeding on the mixotrophic dinoflagellate Gymnodinium aureolum as a function of mean prey concentration (X). (A) Gyrodinium dominans predator, (B) Oxyrrhis marina, (C) Polykrikos kofoidii, (D) Strombidinopsis sp. Symbols represent treatment means \pm 1 SE. A Michaelis-Menten equation (Eq. 2, solid line) and an Ivlev equation (Eq. 3, dashed line) were used to produce curves for (A), (B) and (D) for all treatments in the experiments. (A) $\mu=0.92 \cdot(X-76.2) /[207+(X-76.2)], \mathrm{r}^{2}=0.905$ for Eq. (2) and $\mu=0.79 \cdot\left[1-\mathrm{e}^{-0.00573(X-86.1)}\right], \mathrm{r}^{2}=0.920$ for Eq. (3); (B) $\mu=0.71 \cdot(X-7.8) /[55.2+(X-7.8)], \mathrm{r}^{2}=0.939$ for Eq. (2) and $\mu=0.65 \cdot\left[1-\mathrm{e}^{-0.01612(X-8.9)}\right], \mathrm{r}^{2}=0.930$ for Eq. (3); (D) $\mu=0.44$. $(X-370) /[570+(X-370)], \mathrm{r}^{2}=0.601$ for Eq. (2) and $\mu=0.31 \cdot\left[1-\mathrm{e}^{-0.00372(X-337)}\right], \mathrm{r}^{2}=0.593$ for Eq. (3)

the highest growth rate of $P$. kofoidii feeding on $G$. aureolum was $0.11 \mathrm{~d}^{-1}$.

The specific growth rates of Strombidinopsis sp. feeding on Gymnodinium aureolum increased continuously with increasing mean prey concentration up to ca. $460 \mathrm{ng} \mathrm{C} \mathrm{ml}^{-1}$ (1050 cells ml $\left.{ }^{-1}\right)$, but slowly increased at higher concentrations (Fig. 2D). When the data were fitted to Eq. (2), the $\mu_{\max }$ of Strombidinop- sis sp. feeding on $G$. aureolum was $0.44 \mathrm{~d}^{-1}$. The feeding threshold prey concentration for the growth of the predator (no growth) in Eq. (2) was $370 \mathrm{ng} \mathrm{C}$ $\mathrm{ml}^{-1}\left(840\right.$ cells $\left.\mathrm{ml}^{-1}\right)$. However, when the data were fitted to Eq. (3), the $\mu_{\max }$ of Strombidinopsis sp. feeding on G. aureolum was $0.31 \mathrm{~d}^{-1}$. The feeding threshold prey concentration in Eq. (3) was $340 \mathrm{ng} \mathrm{C} \mathrm{ml}^{-1}$ (770 cells $\mathrm{ml}^{-1}$ ). 


\section{Ingestion and clearance rates}

The ingestion rates of Gyrodinium dominans feeding on Gymnodinium aureolum increased rapidly with increasing mean prey concentration up to ca. 1980 ng C $\mathrm{ml}^{-1}$ (4500 cells $\mathrm{ml}^{-1}$ ), but became saturated at higher concentrations (Fig. 3A). When the data were fitted to Eq. (4), the maximum ingestion rate $\left(I_{\max }\right)$ of $G$. dominans feeding on $G$. aureolum was $2.0 \mathrm{ng} \mathrm{C}$ predator $^{-1}$ $\mathrm{d}^{-1}$ (4.5 cells predator $\left.{ }^{-1} \mathrm{~d}^{-1}\right)$. However, when the data were fitted to Eq. (5), the $I_{\max }$ of $G$. dominans feeding on $G$. aureolum was $1.6 \mathrm{ng} C$ predator ${ }^{-1} \mathrm{~d}^{-1}$ (3.6 cells predator $^{-1} \mathrm{~d}^{-1}$ ). The maximum clearance rate of $G$. dominans feeding on $G$. aureolum was $0.1 \mu$ predator $^{-1} \mathrm{~h}^{-1}$. Gross growth efficiencies (GGEs) of G. dominans feeding on $G$. aureolum at the prey concentrations where the ingestion rates were saturated were 29 to $43 \%$.

The ingestion rates of Oxyrrhis marina feeding on Gymnodinium aureolum increased rapidly with increasing mean prey concentration up to ca. $80 \mathrm{ng} \mathrm{C}$ $\mathrm{ml}^{-1}\left(180\right.$ cells $\left.\mathrm{ml}^{-1}\right)$, but became saturated at higher concentrations (Fig. 3B). When the data were fitted to Eq. (4), the $I_{\max }$ of $O$. marina feeding on G. aureolum was $0.51 \mathrm{ng} C$ predator ${ }^{-1} \mathrm{~d}^{-1}$ (1.2 cells predator $\left.^{-1} \mathrm{~d}^{-1}\right)$. However, when the data were fitted to Eq. (5), the $I_{\max }$ of $O$. marina feeding on G. aureolum was $0.46 \mathrm{ng} C$ predator ${ }^{-1} \mathrm{~d}^{-1}\left(1.0\right.$ cells predator $^{-1}$ $\mathrm{d}^{-1}$ ). The maximum clearance rate of $O$. marina feeding on G. aureolum was $0.2 \mu \mathrm{l}$ predator $^{-1} \mathrm{~h}^{-1}$. GGEs of $O$. marina feeding on $G$. aureolum at the prey concentrations where the ingestion rates were saturated were 29 to $62 \%$.

The ingestion rates of Polykrikos kofoidii feeding on Gymnodinium aureolum continuously increased with increasing mean prey concentration (Fig. 3C). At the given prey concentrations, the highest ingestion rate of $P$. kofoidii feeding on G. aureolum was $2.3 \mathrm{ng} C$ predator $^{-1} \mathrm{~d}^{-1}$ (5.3 cells predator $\left.{ }^{-1} \mathrm{~d}^{-1}\right)$. However, when the data were fitted to both Eq. (5) and Eq. (6) at prey concentrations of $<3770 \mathrm{ng} \mathrm{C}$ predator ${ }^{-1} \mathrm{~d}^{-1}(<8560$ cells predator $^{-1} \mathrm{~d}^{-1}$ ), the $I_{\max }$ of $P$. kofoidii feeding on $G$. aureolum was $2.2 \mathrm{ng} \mathrm{C}$ predator ${ }^{-1} \mathrm{~d}^{-1}$ (5.0 cells predator $^{-1} \mathrm{~d}^{-1}$ ). The maximum clearance rate of $P$. kofoidii feeding on G. aureolum was $2.5 \mu \mathrm{l}$ predator $^{-1} \mathrm{~h}^{-1}$. GGEs of P. kofoidii feeding on G. aureolum at the prey concentrations where the 2 highest ingestion rates were achieved were 29 to $40 \%$.

The ingestion rates of Strombidinopsis sp. feeding on Gymnodinium aureolum increased rapidly with increasing mean prey concentrations $<2280 \mathrm{ng} \mathrm{C} \mathrm{ml}^{-1}$ $\left(<5190\right.$ cells $\left.\mathrm{ml}^{-1}\right)$, but became saturated at higher concentrations (Fig. 3D). When the data were fitted to Eq. (4), the $I_{\max }$ of Strombidinopsis sp. feeding on $G$. aureolum was $69.7 \mathrm{ng} C$ predator ${ }^{-1} \mathrm{~d}^{-1}$ (158 predator $^{-1}$ $\mathrm{d}^{-1}$ ). However, when the data were fitted to Eq. (5), the $I_{\text {max }}$ of Strombidinopsis sp. feeding on G. aureolum was $51.0 \mathrm{ng}$ C predator ${ }^{-1} \mathrm{~d}^{-1}$ (116 cells predator $\left.{ }^{-1} \mathrm{~d}^{-1}\right)$. The maximum clearance rate of Strombidinopsis sp. feeding on G. aureolum was $5.9 \mu \mathrm{l}$ predator $^{-1} \mathrm{~h}^{-1}$. GGEs of $O$. marina feeding on $G$. aureolum at the prey concentrations where the ingestion rates were saturated were 9 to $18 \%$.

\section{Relationships among maximum growth and inges- tion rates of the predators}

Both $\mu_{\max }$ and $I_{\max }$ of Gyrodinium dominans feeding on algal prey were not significantly correlated with prey size (linear regression ANOVA, $p>0.1$; Fig. 4A,B). The $\mu_{\max }$ and $I_{\max }$ of $G$. dominans feeding on Gymnodinium aureolum obtained with Eqs. (2) \& (4) were the second and third highest, respectively, among the algal prey (Fig. 4A,B). The ratio of $\mu_{\max }$ relative to $I_{\max }$ of $G$. dominans feeding on $G$. aureolum was higher than that of the mixotrophic dinoflagellate Heterocapsa triquetra and the raphidophyte Chattonella antiqua (Fig. 4C).

Both $\mu_{\max }$ and $I_{\max }$ of Oxyrrhis marina feeding on algal prey were not significantly correlated with prey size (linear regression ANOVA, p > 0.1; Fig. 5A,B). The $I_{\max }$ of $O$. marina feeding on Gymnodinium aureolum was lower than that for any other algal prey (Fig. 5A). However, the $\mu_{\max }$ of $O$. marina feeding on $G$. aureolum was comparable with that for the haptophyte Isochrysis galbana, the diatom Dunaliella tertiolecta and the raphidophyte Fibrocapsa japonica, while it was lower than that for other algal prey (Fig. 5B). Also, the $\mu_{\max }$ of $O$. marina feeding on the algal prey was not significantly correlated with their $I_{\max }(\mathrm{p}>0.1$; Fig. 5C).

Both $\mu_{\max }$ and $I_{\max }$ of Polykrikos kofoidii feeding on the mixotrophic dinoflagellates showed significant positive correlations with prey size (linear regression ANOVA, $\mathrm{p}<0.05$ for both rates; Fig. 6A,B). The $I_{\max }$ of $P$. kofoidii feeding on Gymnodinium aureolum was the lowest amongst the prey species tested, while the $\mu_{\max }$ of $P$. kofoidii feeding on $G$. aureolum was also almost the lowest (Fig. 6A,B). The $\mu_{\max }$ of $P$. kofoidii feeding on the mixotrophic dinoflagellates also showed significant positive correlations with their $I_{\max }(\mathrm{p}<0.01$; Fig. 6C).

Both $\mu_{\max }$ and $I_{\max }$ of Strombidinopsis sp. on algal prey did not correlate significantly with prey size (linear regression ANOVA, p > 0.1; Fig. 7A,B). The $I_{\max }$ of Strombidinopsis sp. feeding on Gymnodinium aureolum (70 ng $\mathrm{C}$ ciliate $\mathrm{d}^{-1}$ ) are considerably lower than those of Strombidinopsis sp. on the mixotrophic dinoflagellates Lingulodinium polyedrum, Akashiwo sanguinea (previously Gymnodinium 

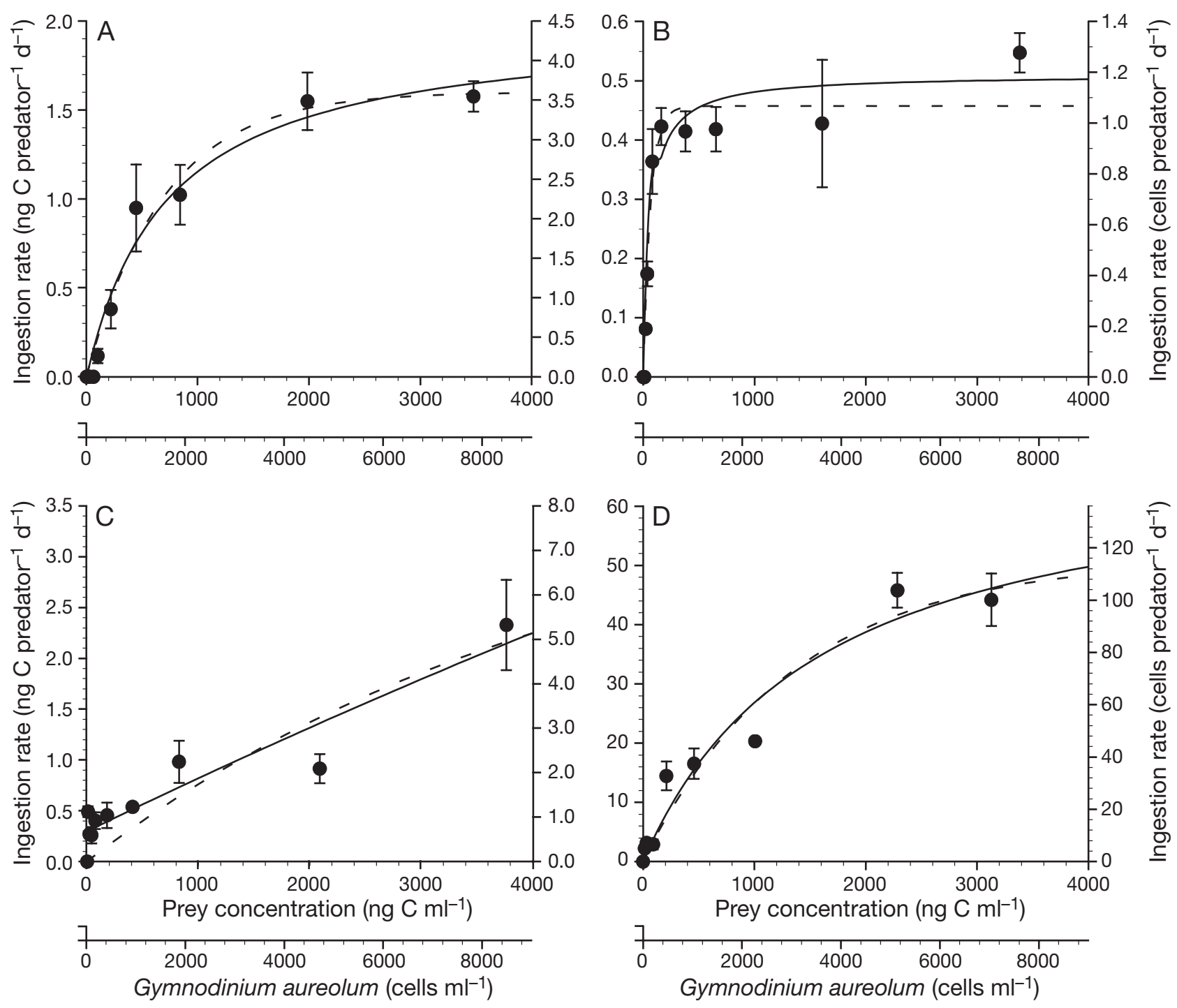

Fig. 3. Ingestion rates (IR, ng C predator ${ }^{-1} \mathrm{~d}^{-1}$ ) of heterotrophic dinoflagellates and a ciliate feeding on the mixotrophic dinoflagellate Gymnodinium aureolum as a function of mean prey concentration $(X)$. (A) Gyrodinium dominans predator, (B) Oxyrrhis marina, (C) Polykrikos kofoidii, (D) Strombidinopsis sp. Symbols represent treatment means \pm 1 SE. A Michaelis-Menten equation (Eq. 4, solid line) and an Ivlev equation (Eq. 5, dashed line) were used to produce the curves for (A), (B) and (D) for all treatments in the experiments. (A) $\mathrm{IR}=2.0 \cdot X /(727+X), \mathrm{r}^{2}=0.905$ for Eq. (4), and IR $=1.6 \cdot\left(1-\mathrm{e}^{-0.00144 X}\right), \mathrm{r}^{2}=0.908$ for Eq. (5); (B) IR $=0.51 \cdot X /(60.6+X), \mathrm{r}^{2}=0.844$ for Eq. (4) and IR $=0.46 \cdot\left(1-\mathrm{e}^{-0.0142 X}\right), \mathrm{r}^{2}=0.857$ for Eq. (5); (D) IR $=69.7 \cdot X /(1599+X)$, $\mathrm{r}^{2}=0.925$ for Eq. (4) and IR $=51.0 \cdot\left(1-\mathrm{e}^{-0.00074 X}\right), \mathrm{r}^{2}=0.924$ for Eq. (5). A logistic equation (Eq. 6, solid line) and an Ivlev equation (Eq. 5, dashed line) were used to produce the curves for (C) at prey concentrations of $<3770 \mathrm{ng} \mathrm{C}^{-}$predator $^{-1} \mathrm{~d}^{-1}\left(<8560 \mathrm{cells}^{-0}\right.$ predator $\left.{ }^{-1} \mathrm{~d}^{-1}\right)$ for all treatments in the experiment. IR $=11 \cdot \ln (X+20610)-109, \mathrm{r}^{2}=0.770$ for Eq. (6) and IR $=5.7 \cdot\left(1-\mathrm{e}^{-0.00013 X}\right)$, $\mathrm{r}^{2}=0.701$ for Eq. (5)

sanguineum), Scrippsiella trochoidea, Cochlodinium polykrikoides and Prorocentrum minimum (207 to $353 \mathrm{ng}$ C ciliate ${ }^{-1} \mathrm{~d}^{-1}$ ) (Fig. 7A). The $\mu_{\max }$ of Strombidinopsis sp. feeding on G. aureolum $\left(0.44 \mathrm{~d}^{-1}\right)$ was lower than for any other mixotrophic dinoflagelllate ( 0.54 to $1.77 \mathrm{~d}^{-1}$ ). The $\mu_{\max }$ of Strombidinopsis sp. on the mixotrophic dinoflagellate was significantly and positively correlated with their $I_{\max }(\mathrm{p}<$ 0.05; Fig. 7C).

\section{Grazing impact}

When the abundances of Gymnodinium aureolum and small heterotrophic Gyrodinium spp. (25 to $35 \mu \mathrm{m}$ in cell length) in the coastal waters off Saemankeum, Korea, in 2006 to 2007 (sample size $\mathrm{n}=27$ ) were 13 to 4033 cells ml ${ }^{-1}$ and 2 to 78 cells ml ${ }^{-1}$, respectively, grazing coefficients attributable to small heterotrophic Gyrodinium spp. on co-occurring G. aureolum were 

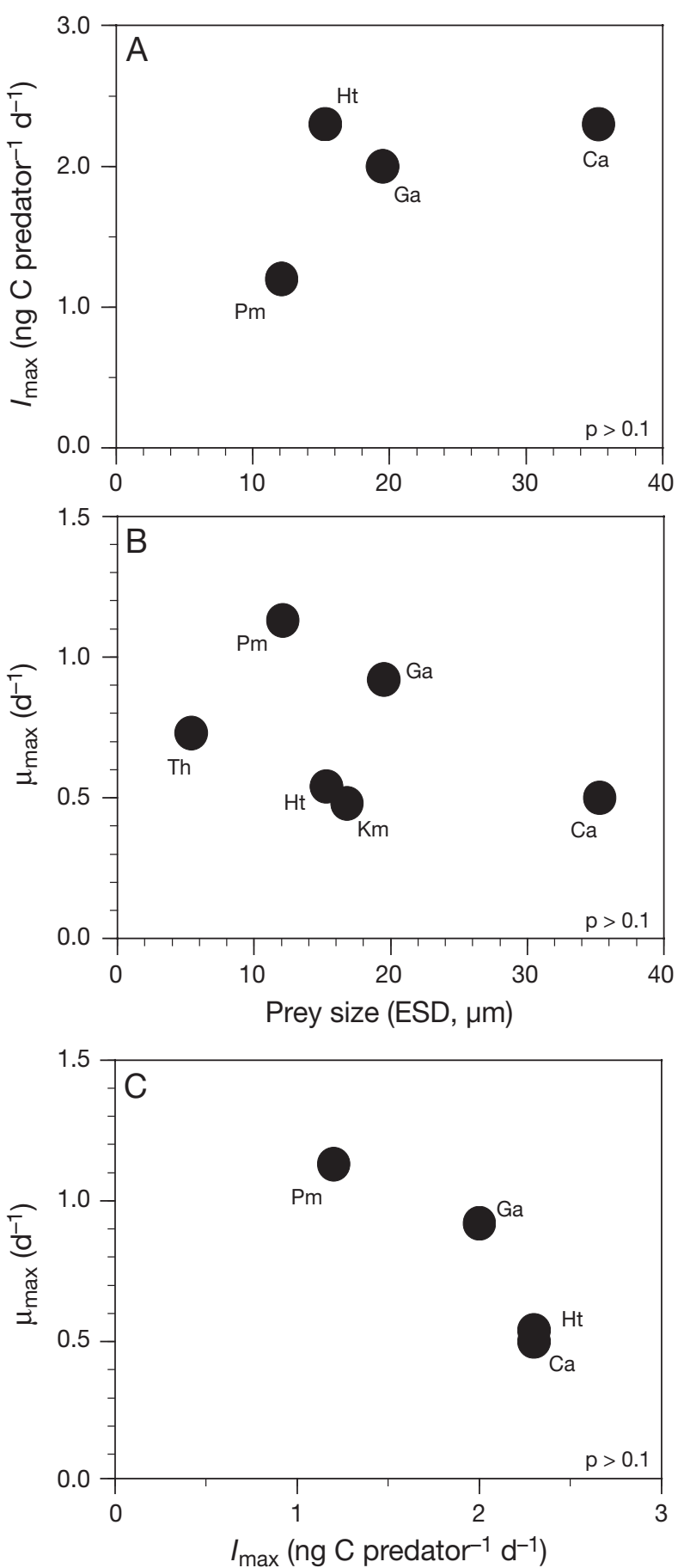

Fig. 4. Gyrodinium dominans. (A) Maximum ingestion $\left(I_{\max }\right)$ and (B) growth rates $\left(\mu_{\max }\right)$ of $G$. dominans feeding on autotrophic/mixotrophic algal prey ( ) as a function of prey size (equivalent spherical diameter [ESD], $\mu \mathrm{m}$ ) and (C) $\mu_{\max }$ as a function of the $I_{\max }$. The p-values in (A), (B) and (C) were all $\mathrm{p}>0.1$ (linear regression ANOVA). Ca: Chattonella antiqua; Ga: Gymnodinium aureolum; Ht: Heterocpasa triquetra; Km: Karenia mikimotoi; Pm: Prorocentrum minimum; Th: Thalassiosira sp. $I_{\max }$ and/or $\mu_{\max }$ on algal prey were obtained from Nakamura et al. $(1992,1995)$ and Kim \& Jeong (2004)
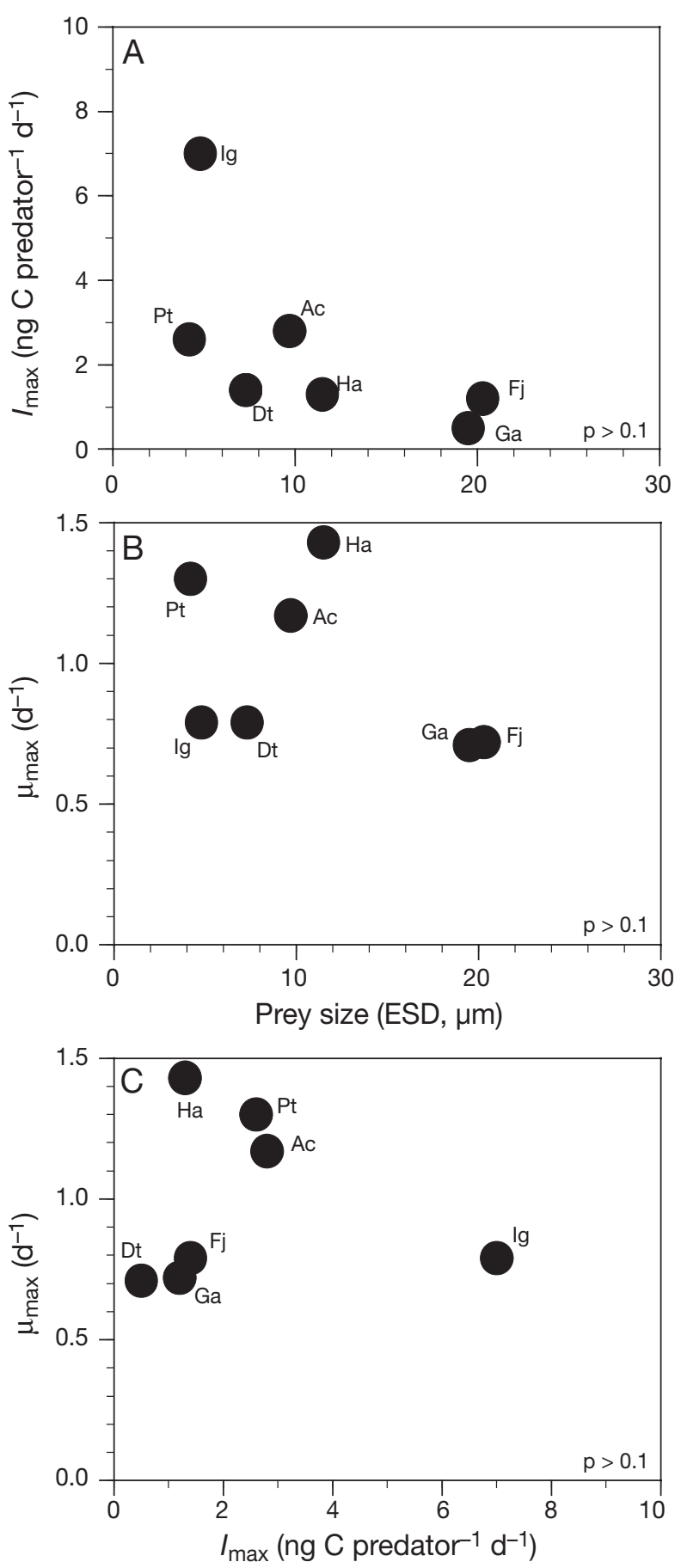

Fig. 5. Oxyrrhis marina. (A) Maximum ingestion ( $\left.I_{\max }\right)$ and (B) growth rates $\left(\mu_{\max }\right)$ of $O$. marina feeding on autotrophic/ mixotrophic algal prey () as a function of prey size (equivalent spherical diameter [ESD], $\mu \mathrm{m}$ ) and (C) $\mu_{\max }$ as a function of $I_{\max }$. The p-values in (A), (B) and (C) were all $\mathrm{p}>0.1$ (linear regression ANOVA). Ac: Amphidinium carterae; Dt: Dunaliella tertiolecta; Fj: Fibrocapsa japonica; Ga: Gymnodinium aureolum; Ha: Heterosigma akashiwo; Ig: Isochrysis galbana; Pt: Phaeodactylum tricornutum. $I_{\max }$ and/or $\mu_{\max }$ on algal prey were obtained from Goldman et al. (1989), Jeong et al. (2001a, 2003b), and Tillmann \& Reckermann (2002) 

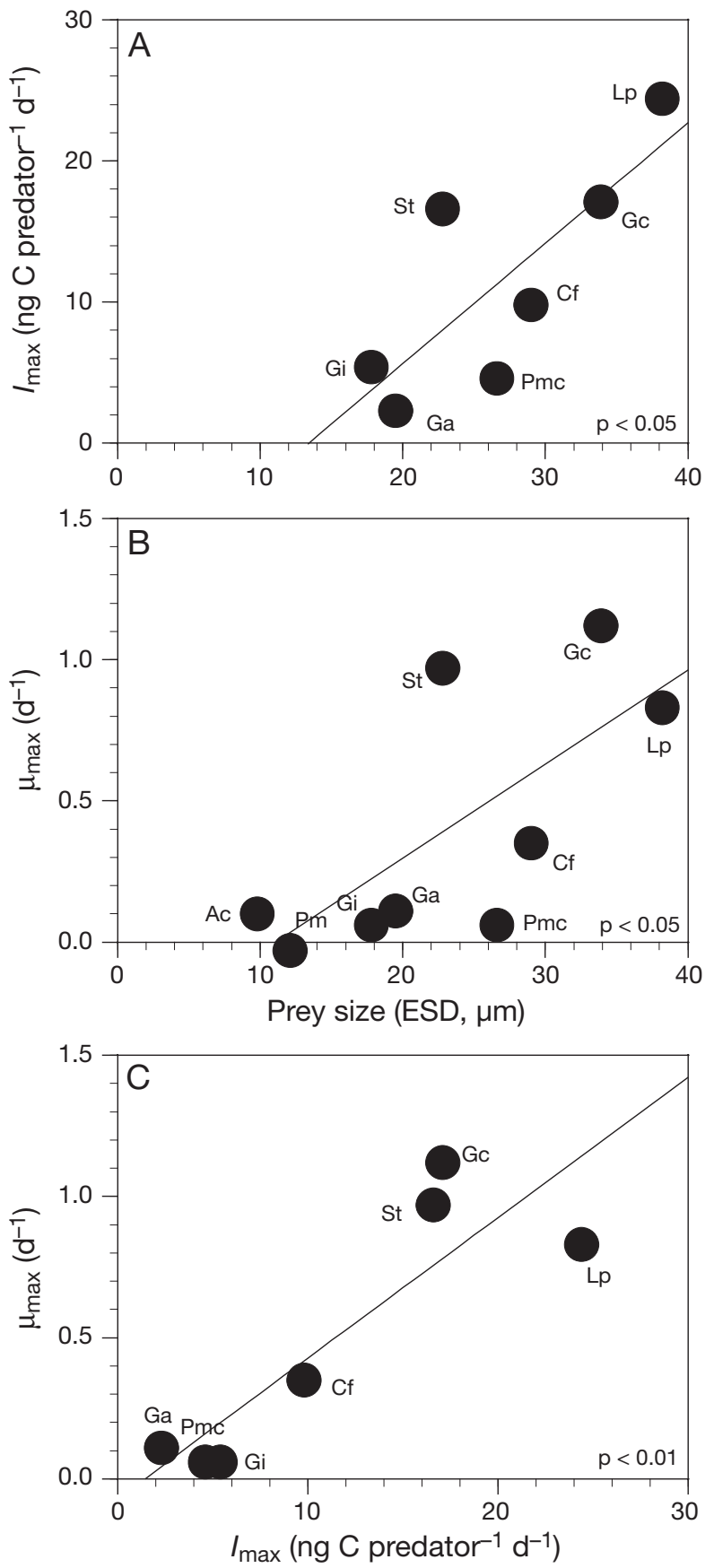

Fig. 6. Polykrikos kofoidii. Maximum (A) ingestion $\left(I_{\max }, \mathrm{ng} \mathrm{C}\right.$ predator $\left.{ }^{-1} \mathrm{~d}^{-1}\right)$ and $(\mathrm{B})$ growth rates $\left(\mu_{\max }, \mathrm{d}^{-1}\right)$ of $P$. kofoidii on autotrophic/mixotrophic algal prey () as a function of prey size (equivalent spherical diameter $[\mathrm{ESD}], \mu \mathrm{m}$ ) and $(\mathrm{C}) \mu_{\max }$ as a function of $I_{\max }$. The p-values in (A) and (B) were $\mathrm{p}<0.05$, but the $\mathrm{p}$-value in $(\mathrm{C})$ was $\mathrm{p}<0.01$ (linear regression ANOVA). The equations of the linear regression were: (A) $I_{\max }=0.853 \cdot \mathrm{ESD}-11.4, \mathrm{r}^{2}=0.616 ;$ (B) $\mu_{\max }=0.0331 \cdot \mathrm{ESD}-$ $0.375, \mathrm{r}^{2}=0.494 ;$ (C) $\mu_{\max }=0.0497 \cdot I_{\max }-0.0695, \mathrm{r}^{2}=0.767$. Ac: Amphidinium carterae; Cf: Ceratium furca; Ga: Gymnodinium aureolum; Gc: Gymnodinium catenatum; Gi: Gymnodinium impudicum; Lp: Lingulodinium polyedrum; Pmc: Prorocentrum micans; Pm: P. minimum; St: Scrippsiella trochoidea. $I_{\max }$ and/or $\mu_{\max }$ on algal prey were obtained from Jeong et al. (2001b)
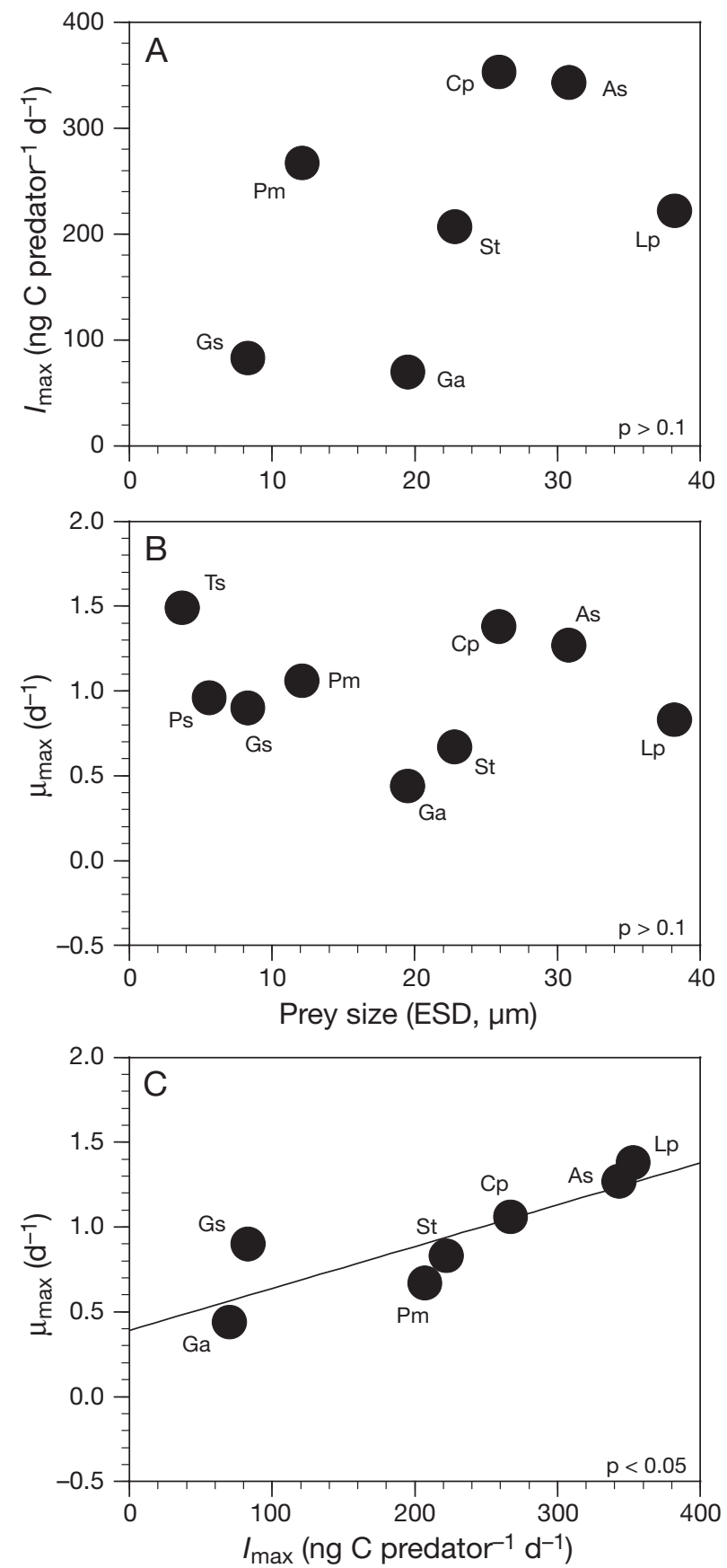

Fig. 7. Strombidinopsis sp. Maximum (A) ingestion $\left(I_{\max }\right.$ ng C predator $\left.{ }^{-1} \mathrm{~d}^{-1}\right)$ and (B) growth rates $\left(\mu_{\max }, \mathrm{d}^{-1}\right)$ of Strombidinopsis sp. on autotrophic/mixotrophic algal prey (O) as a function of prey size (equivalent spherical diameter [ESD], $\mu \mathrm{m}$ ) and (C) $\mu_{\max }$ as a function of the $I_{\max }$. The p-values in (A) and (B) were $\mathrm{p}>0.1$, but the $\mathrm{p}$-value in (C) was $\mathrm{p}<0.05$ (linear regression ANOVA). The equations of the linear regression for autotrophic/mixotrophic algal prey only was (C) $\mu_{\max }=0.003$. $I_{\max }+0.391, \mathrm{r}^{2}=712$. As: Akashiwo sanguinea; Cp: Cochlodinium polykrikoides; Ga: Gymnodinium aureolum; Gs: G. simplex; Lp: Lingulodinium polyedrum; Pm: Prorocentrum minimum; Ps: Pryenomonas salina; St: Scrippsiella trochoidea; Ts: Thalassiosira pseudonana. $I_{\max }$ and/or $\mu_{\max }$ on algal prey were obtained from Buskey \& Hyatt (1995), Montagnes et al. (1996), Jeong et al. (1999), and Montagnes \& Lessard (1999) 
0.002 to $0.40 \mathrm{~d}^{-1}$ (Fig. 8A). In addition, when the abundances of Gymnodinium aureolum and large Strombidinopsis spp. (>70 $\mathrm{m}$ in cell length) in the coastal waters off Saemankeum in 2006 to 2008 (sample size $\mathrm{n}=20$ ) were 10 to $4425 \mathrm{cells} \mathrm{ml}^{-1}$ and 0.1 to 3.8 cells $\mathrm{ml}^{-1}$, respectively, grazing coefficients attributable to large Strombidinopsis spp. on co-occurring Gymnodinium aureolum were 0.007 to $0.25 \mathrm{~d}^{-1}$ (Fig. 8B).

\section{DISCUSSION}

\section{Feeding occurrence}

This study is the first report on feeding by heterotrophic dinoflagellates and ciliates on actual Gymnodinium aureolum since the confusion over taxonomy was settled (Daugbjerg et al. 2000, Hansen et al. 2000).
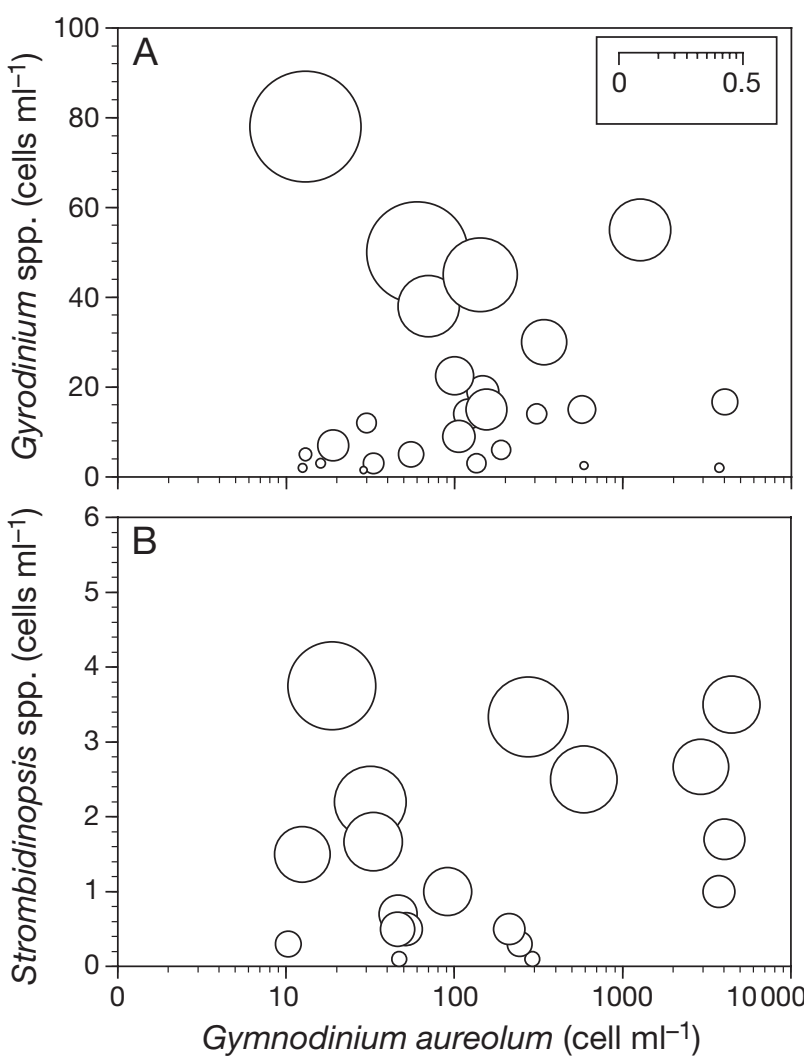

Fig. 8. Gyrodinium spp. and Strombidinopsis spp. Calculated grazing coefficients of (A) small heterotrophic Gyrodinium spp. $(\mathrm{n}=27)$ and (B) Strombidinopsis spp. $(\mathrm{n}=20)$ in relation to the concentration of co-occurring Gymnodinium aureolum see Eq. (7) for calculation). Clearance rates, measured under the conditions provided in the present study, were corrected with a $Q_{10}=2.8$ (Hansen et al. 1997) because in situ water temperatures and the temperature used in the laboratory for this experiment $\left(20^{\circ} \mathrm{C}\right)$ were sometimes different. Inset shows the scale of the circles that represent grazing coefficients $\left(g, \mathrm{~d}^{-1}\right)$
Gyrodinium dominans, Oxyrrhis marina, Polykrikos kofoidii and Strombidinopsis spp. are known to feed on prey by engulfing them (Kim \& Jeong 2004, Nakamura et al. 1995, Jeong et al. 2001a, 2003a, 2008a), while Pfiesteria piscicida, Protoperidinium bipes and Stoeckeria algicida feed by means of the peduncle or pallium (Burkholder \& Glasgow 2001, Jeong et al. 2004, 2005). Therefore, the heterotrophic protists that feed by engulfing their prey and were tested in the present study were able to feed on G. aureolum, whereas those that feed using their peduncle or pallium did not feed on G. aureolum. P. piscicida, P. bipes, and S. algicida did not deploy a tow filament to capture G. aureolum cells. P. piscicida is known to to feed on the naked mixotrophic dinoflagellates Cochlodinium polykrikoides, Akashiwo sanguinea and Gymnodinium catenatum, which are larger than G. aureolum (Jeong et al. 2006). Furthermore, the mean swimming speeds of $C$. polykrikoides and G. catenatum (450 to $1060 \mu \mathrm{m} \mathrm{s}^{-1}$ ) are greater than that of G. aureolum $\left(390 \mu \mathrm{m} \mathrm{s}^{-1}\right)$, while the speed achieved by $A$. sanguinea $\left(190 \mu \mathrm{m} \mathrm{s}^{-1}\right)$ is slower than that of G. aureolum (Jeong et al. 1999, 2010, authors' unpubl. data). Therefore, size and/or swimming speed of G. aureolum may not be primarily responsible for nonfeeding of $P$. piscicida on G. aureolum. On the other hand, G. dominans, O. marina, $P$. kofoidii and Strombidinopsis spp. are comparable in size or larger than G. aureolum, while P. piscicida, $P$. bipes and $S$. algicida are smaller. Therefore, the size of the predators may affect their ability to feed on $G$. aureolum. On the basis of the results of the present study, a high abundance of large heterotrophic dinoflagellates and/or ciliates that engulf their prey, but no or low abundance of heterotrophic dinoflagellates that feed using their small peduncle or pallium is expected to occur during red tides dominated by G. aureolum.

Oxyrrhis marina and Polykrikos kofoidii are known to be killed by the toxic mixotrophic dinoflagellate Alexandrium tamarense at concentrations of ca. 3000 to 4000 cells ml$^{-1}$ (Cho \& Matsuoka 2000, Tillmann \& John 2002). The present study showed that $O$. marina and P. kofoidii grew well while feeding on Gymnodinium aureolum. This suggests that $G$. aureolum is not toxic or has much weaker toxins than $A$. tamarense. Furthermore, the large ciliate Strombidinopsis sp. used in this study fed and grew well on G. aureolum, while K. mikimotoi (previously Gyrodinium aureolum) is known to be harmful to the large ciliate Favella ehrenbergii (Hansen 1995). This evidence confirmed that, unlike K. mikimotoi, Gymnodinium aureolum does not have toxic compounds strong enough to kill larval fish and/or brine shrimp as reported by Tang et al. (2008) and Jeong et al. (2010). There have been some studies reporting harmful effects by $K$. mikimotoi on gut tissues as determined by 
histological examination of some juvenile bivalve mollusks, such as the bay scallop Argopecten irradians and the oyster Crassostrea virginica (Smolowitz \& Shumway 1997). The copepods Pseudocalanus elongates and Temora longicornis are known to select the nontoxic dinoflagellate Gyrodinium instriatum in preference to $K$. mikimotoi (Schultz \& Kioerboe 2009). However, on the basis of the results of the present study, there is a high probability that $G$. aureolum does not have harmful effects on these larvae at the histological level and copepods may not select nontoxic dinoflagellate prey in preference to G. aureolum.

\section{Growth and ingestion rates}

The $\mu_{\max }$ and $I_{\max }$ of Gyrodinium dominans, Oxyrrhis marina and Strombidinopsis sp. feeding on Gymnodinium aureolum obtained by means of MichaelisMenten equations (Eqs. 2 \& 4) were slightly higher than those obtained by means of Ivlev equations (Eqs. 3 \& 5), even though $r^{2}$-values of both equations for each data set were similar. There were 2 characteristic differences between these 2 equations. The rate of increase in the growth or ingestion rates at low and medium prey concentrations in the Ivlev equations were higher than those determined from MichaelisMenten equations; however, $\mu_{\max }$ and $I_{\max }$ obtained by means of Michaelis-Menten equations were higher than those obtained by means of Ivlev equation because the rates obtained from the Michaelis-Menten equations continuously and detectably increased, while those obtained from the Ivlev equations continuously, but undetectably, increased. Thus, an Ivlev equation may produce the best fit curve for both growth and ingestion rates of $G$. dominans, while a Michaelis-Menten equation may produce the best fit curve for growth and ingestion rates of $O$. marina and Strombidinopsis spp.

The $\mu_{\max }$ and $I_{\max }$ of Polykrikos kofoidii, Oxyrrhis marina, and Strombidinopsis sp. when feeding on Gymnodinium aureolum obtained using Eqs. (2) \& (4) were lower than that when they fed on any other algal prey (Figs. 4 to 7 ). The $\mu_{\max }$ and $I_{\max }$ of $P$. kofoidii when feeding on the algal prey showed significant positive correlations with prey size. Thus, the almost smallest size of $G$. aureolum may be mainly responsible for these lower $\mu_{\max }$ and $I_{\max }$ of $P$. kofoidii compared with the other prey. Interestingly, $G$. aureolum is almost the largest of the prey species on which $O$. marina is able to feed. O. marina may have difficulty in capturing and ingesting this large edible prey, and this may be mainly responsible for the lower $\mu_{\max }$ and $I_{\max }$ of $G$. aureolum. The size of $G$. aureolum was middle among the sizes of the edible prey species for Strombidinopsis sp. Large ciliates such as Strombidinopsis spp. and Favella ehrenbergii have been reported to be negatively affected by the presence of toxic algal prey; the growth rates of Strombidinopsis spp. and F. ehrenbergii decreased when the toxic dinoflagellates Amphidinium carterae and Alexandrium tamarense, respectively, were provided as prey (Hansen 1995, Jeong et al. 1999). Thus, G. aureolum may have weak toxins that negatively affect the growth and ingestion of Strombidinopsis spp., but do not negatively affect its survival. The size of $G$. aureolum was intermediate among the sizes of the edible prey species for Gyrodinium dominans as well. However, unlike Strombidinopsis sp., the $\mu_{\max }$ and $I_{\max }$ of $G$. dominans feeding on $G$. aureolum were comparable with or higher than those when feeding on the algal prey. Several heterotrophic dinoflagellates have been known to detoxify phytotoxins (Jeong et al. 2001a, 2003a). G. dominans grew well on the toxic dinoflagellate Karenia mikimotoi (previously Gymnodinium mikimotoi) $\left(0.48 \mathrm{~d}^{-1}\right.$ when corrected to $20^{\circ} \mathrm{C}$ using a $Q_{10}$ of 2.8 , Hansen et al. 1997), even though the $\mu_{\max }$ of $G$. dominans on $K$. mikimotoi was half the $\mu_{\max }$ on $G$. aureolum $\left(0.9 \mathrm{~d}^{-1}\right)$. Therefore, G. aureolum may affect the growth and ingestion of diverse predators in several different ways (e.g. lower and upper prey size limits, presence and toxicity of toxins).

The $\mu_{\max }$ of Polykrikos kofoidii and Strombidinopsis sp. on the mixotrophic dinoflagellates showed significant positive correlations with $I_{\max }$, while that of Gyrodinium dominans and Oxyrrhis marina did not. The $I_{\max }$ of $P$. kofoidii and Strombidinopsis spp. on the mixotrophic dinoflagellates were 2.3 to $24.4 \mathrm{ng} \mathrm{C}$ predator $^{-1} \mathrm{~d}^{-1}$ and 70 to $353 \mathrm{ng} \mathrm{C}$ predator $^{-1} \mathrm{~d}^{-1}$, respectively, while that of $G$. dominans and $O$. marina were 1.2 to $2.3 \mathrm{ng} C$ predator ${ }^{-1} \mathrm{~d}^{-1}$ and 0.3 to $7.0 \mathrm{ng} \mathrm{C}$ predator $^{-1} \mathrm{~d}^{-1}$, respectively. This evidence suggests that $P$. kofoidii and Strombidinopsis sp. may not have difficulty in capturing and ingesting these algal preys and are able to convert ingested carbon to body carbon at similar rates, regardless of the prey species (i.e. they may effectively digest any prey). In contrast, G. dominans and $O$. marina may have difficulty in capturing and ingesting these algal prey, in particular large prey species (i.e. differential energy spent for feeding) and/or may convert ingested carbon to body carbon at different rates for different prey species (i.e. small predators may digest some prey easily and others with more difficulty).

\section{Grazing impact}

Grazing coefficients attributable to small heterotrophic Gyrodinium spp. (25 to $35 \mu \mathrm{m}$ in cell length) on 
co-occurring Gymnodinium aureolum in the coastal waters off Saemankeum in 2006 to 2007 ranged between 0.002 and $0.40 \mathrm{~d}^{-1}$ (i.e. up to $33 \%$ of G. aureolum populations could be removed by small Gyrodinium populations in $1 \mathrm{~d}$ ). Grazing coefficients attributable to Gyrodinium dominans were high (2 to 78 cells ml-1) in a wide range of G. aureolum abundances (13 to 4033 cells ml $^{-1}$ ). We assumed that the ingestion rates of the other small heterotrophic Gyrodinium spp. feeding on $G$. aureolum are the same as that of G. dominans. Gyrodinium guttula co-occurs in the sampling waters, but it was not distinguishable from G. dominans in fixed samples under light microscope. We did not measure the growth and ingestion rates of G. guttula feeding on G. aureolum because we do not have a culture of this species. Thus, our estimation may be under- or overestimated if the growth and ingestion rates of G. guttula feeding on G. aureolum are significantly different from those of $G$. dominans and the abundance of G. guttula is not negligible.

In addition, grazing coefficients attributable to Strombidinopsis spp. (>70 $\mu \mathrm{m}$ in cell length) on cooccurring Gymnodinium aureolum in the coastal waters off Saemankeum in 2006 to 2008 were 0.007 to $0.25 \mathrm{~d}^{-1}$ (i.e. up to $22 \%$ of $G$. aureolum populations could be removed by large Strombidinopsis populations in $1 \mathrm{~d})$. Grazing coefficients attributable to Strom-

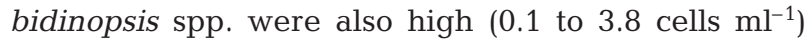
in a wide range of $G$. aureolum abundances (20 to 4030 cells ml$^{-1}$ ). Therefore, the populations of Strombidinopsis spp. or Gyrodinium dominans may have a considerable grazing impact on G. aureolum not only during the development or declining stages of red tides dominated by G. aureolum, but also at the fully developed stage of these red tides.

Studies on the formation, persistence and decline of red tide suggest that grazing pressure may sometimes play an important role in bloom dynamics (Watras et al. 1985, Turner et al. 1998, Turner 2006). In particular, grazing by heterotrophic protists is believed to contribute to the decline of red tides or cause changes in the abundance of the causative species (Jeong 1995, Kamiyama \& Matsuyama 2005, Turner 2006, Buskey 2008, Stoecker et al. 2008). This study is an important example showing that grazing by heterotrophic dinoflagellates and ciliates may contribute to the decline of red tides.

Some studies have suggested a biological method for controlling red tides using mass cultured grazers (Jeong et al. 2003b, 2008a). Strombidinopsis spp. or Gyrodinium dominans are strong candidates for developing a biological method for controlling Gymnodinium aureolum red tides by increasing the abundance of these predators and introducing them to aqua cages in natural environments or aqua tanks on land.
Acknowledgements. We thank Dr. K. A. Seong for technical support and E. Potvin for improving the English of the manuscript. This paper was funded by grants from the National Research Foundation (2009-0058298) and an award to H.J.J. from the Ecological Disturbance Research Program, Korea Institute of Marine Science and Technology Promotion, Ministry of Land, Transportation and Marine Affairs (KMLTM), and an award to J.S.K. from the Korean Research Foundation (KRF-2007-359-C00042).

\section{LITERATURE CITED}

Blasco D, Berard-Therriault L, Levasseur M, Vrieling EG (1996) Temporal and spatial distribution of the ichthyotoxic dinoflagellate Gyrodinium aureolum Hulburt in the St Lawrence, Canada. J Plankton Res 18:1917-1930

Burkholder JAM, Glasgow HB Jr (2001) History of toxic Pfiesteria in North Carolina estuaries from 1991 to the present. BioScience 51:827-841

Buskey EJ (2008) How does eutrophication affect the role of grazers in harmful algal bloom dynamics? Harmful Algae 8:152-157

> Buskey EJ, Hyatt CJ (1995) Effects of the Texas (USA) 'brown tide' alga on planktonic grazers. Mar Ecol Prog Ser 126: 285-292

Calbet A, Landry M (2004) Phytoplankton growth, microzooplankton grazing, and carbon cycling in marine ecosystems. Limnol Oceanogr 49:51-57

Calbet A, Vaqué D, Felipe J, Vila M, Sala MM, Alcaraz M, Estrada M (2003) Relative grazing impact of microzooplankton and mesozooplankton on a bloom of the toxic dinoflagellate Alexandrium minutum. Mar Ecol Prog Ser 259:303-309

Cho HJ, Matsuoka K (2000) Cell lysis of a phagotrophic dinoflagellate, Polykrikos kofoidii, feeding on Alexandrium tamarense. Plankton Biol Ecol 47:134-136

Daugbjerg N, Hansen G, Larsen J, Moestrup Ø (2000) Phylogeny of some major genera of dinoflagellates based on ultrastructure and partial LSU rDNA sequence data, including the erection of 3 new genera of unarmoured dinoflagellates. Phycologia 39:302-317

Frost BW (1972) Effects of size and concentration of food particles on the feeding behavior of the marine planktonic copepod Calanus pacificus. Limnol Oceanogr 17: $805-815$

Gill CW, Harris RP (1987) Behavioural responses of the copepods Calanus helgolandicus and Temora longicornis to dinoflagellate diets. J Mar Biol Assoc UK 67:785-801

Goldman JC, Dennett MR, Gordin H (1989) Dynamics of herbivorous grazing by the heterotrophic dinoflagellate Oxyrrhis marina. J Plankton Res 11:391-407

Hansen PJ (1995) Growth and grazing response of a ciliate feeding on the red tide dinoflagellate Gyrodinium aureolum in monoculture and in mixture with a non-toxic alga. Mar Ecol Prog Ser 121:65-72

> Hansen G, Daugbjerg N, Henriksen P (2000) Comparative study of Gymnodinium mikomotoi and Gymnodinium aureolum, comb. nov. (=Gyrodinium aureolum) based on morphology, pigment composition, and molecular data. J Phycol 36:394-410

Hansen PJ, Bjornsen PK, Hansen BW (1997) Zooplankton grazing and growth: scaling within the $2-2,000-\mu \mathrm{m}$ body size range. Limnol Oceanogr 42:687-704

Heinbokel JF (1978) Studies on the functional role of tintinnids in the Southern California Bight. I. Grazing and growth rates in laboratory cultures. Mar Biol 47:177-189 
Hulburt EM (1957) The taxonomy of unarmored Dinophyceae of shallow embayments on Cape Cod, Massachusetts. Biol Bull (Woods Hole) 112:196-219

Jeong HJ (1995) The interactions between microzooplanktonic grazers and dinoflagellates causing red tides in the open coastal waters off southern California. PhD thesis. University of California, San Diego, CA

Jeong HJ, Shim JH, Lee CW, Kim JS, Koh SM (1999) Growth and grazing rates of the marine planktonic ciliate Strombidinopsis sp. on red-tide and toxic dinoflagellates. J Eukaryot Microbiol 46:69-76

Jeong HJ, Kang HJ, Shim JS, Park JY, Kim JS, Song JY, Choi HJ (2001a) Interactions among the toxic dinoflagellate Amphidinium carterae, the heterotrophic dinoflagellate Oxyrrhis marina, and the calanoid copepods Acartia spp. Mar Ecol Prog Ser 218:77-86

Jeong HJ, Kim SK, Kim JS, Kim ST, Yoo YD, Yoon JY (2001b) Growth and grazing rates of the heterotrophic dinoflagellate Polykrikos kofoidii on red-tide and toxic dinoflagellates. J Eukaryot Microbiol 48:298-308

> Jeong HJ, Park KH, Kim JS, Kang HJ and others (2003a) Reduction in the toxicity of the dinoflagellate Gymnodinium catenatum when fed on by the heterotrophic dinoflagellate Polykrikos kofoidii. Aquat Microb Ecol 31: 307-312

Jeong HJ, Kim JS, Yoo YD, Kim ST and others (2003b) Feeding by the heterotrophic dinoflagellate Oxyrrhis marina on the red-tide raphidophyte Heterosigma akashiwo: a potential biological method to control red tides using mass-cultured grazers. J Eukaryot Microbiol 50: $274-282$

> Jeong HJ, Yoo YD, Kim ST, Kang NS (2004) Feeding by the heterotrophic dinoflagellate Protoperidinium bipes on the diatom Skeletonema costatum. Aquat Microb Ecol 36: 171-179

> Jeong HJ, Kim JS, Kim JH, Kim ST and others (2005) Feeding and grazing impact by the newly described heterotrophic dinoflagellate Stoeckeria algicida on the harmful alga Heterosigma akashiwo. Mar Ecol Prog Ser 295:69-78

> Jeong HJ, Ha JH, Park JY, Kim JH and others (2006) Distribution of the heterotrophic dinoflagellate Pfiesteria piscicida in Korean waters and its consumption of mixotrophic dinoflagellates, raphidophytes, and fish blood cells. Aquat Microb Ecol 44:263-278

> Jeong HJ, Kim JS, Song JY, Kim JH, Kim TH, Kim SK, Kang NS (2007) Feeding by heterotrophic protists and copepods on the heterotrophic dinoflagellates Pfiesteria pisicicida, Stoeckeria algicida, and Luciella masanensis. Mar Ecol Prog Ser 349:199-211

Jeong HJ, Kim JS, Yoo YD, Kim ST and others (2008a) Control of the harmful alga Cochlodinium polykrikoides by the naked ciliate Strombidinopsis jeokjo in mesocosm enclosures. Harmful Algae 7:368-377

Jeong HJ, Seong KA, Yoo YD, Kim TH and others (2008b) Feeding and grazing impact by the small marine heterotrophic dinoflagellates on heterotrophic bacteria. J Eukaryot Microbiol 55:271-288

Jeong HJ, Yoo YD, Kang NS, Rho JR and others (2010) Ecology of Gymnodinium aureolum. I. Feeding in western Korean waters. Aquat Microb Ecol 59:239-255

Kamiyama T, Arima S (2001) Feeding characteristics of two tintinnid ciliate species on phytoplankton including harmful species: effects of prey size on ingestion rates and selectivity. J Exp Mar Biol Ecol 257:281-296

Kamiyama T, Matsuyama Y (2005) Temporal changes in the ciliate assemblage and consecutive estimates of their grazing effect during the course of a Heterocapsa circular- isquama bloom. J Plankton Res 27:303-311

Kim JS, Jeong HJ (2004) Feeding by the heterotrophic dinoflagellates Gyrodinium dominans and G. spirale on the red-tide dinoflagellate Prorocentrum minimum. Mar Ecol Prog Ser 280:85-94

Lee JK, Hirayama K (1992) The food removal rate by Noctiluca scintillans feeding on Tetraselmis tetrathelle and Gymnodinium nagasakiense. Bull Fac Fish Nagasaki Univ 71:169-175

Menden-Deuer S, Lessard E (2000) Carbon to volume relationships for dinoflagellates, diatoms, and other protist plankton. Limnol Oceanogr 45:569-579

Montagnes DJS, Lessard EJ (1999) Population dynamics of the marine planktonic ciliate Strombidinopsis multiauris: its potential to control phytoplankton blooms. Aquat Microb Ecol 20:167-181

Montagnes DJS, Berger JD, Taylor FJR (1996) Growth rate of the marine planktonic ciliate Strombidinopsis cheshiri Snyder and Ohman as a function of food concentration and interclonal variability. J Exp Mar Biol Ecol 206: $121-132$

Nakamura Y, Yamazaki Y, Hiromi J (1992) Growth and grazing of a heterotrophic dinoflagellate, Gyrodinium dominans, feeding on a red tide flagellate, Chattonella antiqua. Mar Ecol Prog Ser 82:275-279

Nakamura Y, Suzuki SY, Hiromi J (1995) Growth and grazing of a naked heterotrophic dinoflagellate, Gyrodinium dominans. Aquat Microb Ecol 9:157-164

Naustvoll LJ (1998) Growth and grazing by the thecate heterotrophic dinoflagellate Diplopsalis lenticula (Diplopsalidaceae, Dinophyceae). Phycologia 37:1-9

Nielsen MV, Tønseth CP (1991) Temperature and salinity effect on growth and chemical composition of Gyrodinium aureolum Hulburt in culture. J Plankton Res 13:389-398

Potts GW, Edwards JM (1987) Impact of a Gyrodinium aureolum bloom on inshore young fish populations. J Mar Biol Assoc UK 67:293-297

Schultz M, Kioerboe T (2009) Active prey selection in two pelagic copepods feeding on potentially toxic and nontoxic dinoflagellates. J Plankton Res 31:553-561

Smolowitz R, Shumway SE (1997) Possible cytotoxic effects of the dinoflagellate, Gyrodinium aureolum, on juvenile bivalve mollusks. Aquac Int 5:291-300

Stoecker DK, Thessen AE, Gustafson DE (2008) 'Windows of opportunity' for dinoflagellate blooms: reduced microzooplankton net growth coupled to eutrophication. Harmful Algae 8:158-166

Tang YZ, Egerton TA, Kong L, Marshall HG (2008) Morphological variation and phylogenetic analysis of the dinoflagellate Gymnodinium aureolum from a tributary of Chesapeake Bay. J Eukaryot Microbiol 55:91-99

Tangen K (1977) Blooms of Gyrodinium aureolum (Dinophyceae) in north European waters, accompanied by mortality in marine organisms. Sarsia 63:123-133

Tillmann U, John U (2002) Toxic effects of Alexandrium spp. on heterotrophic dinoflagellates: an allelochemical defense mechanism independent of PSP-toxin content. Mar Ecol Prog Ser 230:47-58

Tillmann U, Reckermann M (2002) Dinoflagellate grazing on the raphidophyte Fibrocapsa japonica. Aquat Microb Ecol 26:247-257

Turner JT, Borkman DG (2005) Impact of zooplankton grazing on Alexandrium blooms in the offshore Gulf of Maine. Deep-Sea Res II 52:2801-2816

Turner JT, Tester PA, Hansen PJ (1998) Interactions between toxic marine phytoplankton and metazoan and protistan grazers. In: Anderson DM, Cembella AD, Hallegraeff GM 
(eds) Phytoplankton ecology of harmful algal blooms. NATO ASI Ser 41. Springer, Berlin, p 453-473

Turner JT (2006) Harmful algae interactions with marine planktonic grazers. In: Granéli E, Turner JT (eds) Ecology of harmful algae. Springer-Verlag, Berlin, p 259-270

Uye S, Takamatsu K (1990) Feeding interactions between planktonic copepods and red-tide flagellates from Japanese coastal waters. Mar Ecol Prog Ser 59:97-107

Editorial responsibility: Robert Sanders,

Philadelphia, Pennsylvania, USA
Watras CJ, Garcon VC, Olson RJ, Chishom SW, Anderson DM (1985) The effect of zooplankton grazing on estuarine blooms of the toxic dinoflagellate Gonyaulax tamarensis. J Plankton Res 7:891-908

Yamasaki Y, Kim D, Matsuyama Y, Oda T, Honjo T (2004) Production of superoxide anion and hydrogen peroxide by the red tide dinoflagellate Karenia mikimotoi. J Biosci Bioeng 97:212-215

Submitted: August 17, 2009; Accepted: January 13, 2010

Proofs received from author(s): April 12, 2010 